\title{
A CASE FOR VALUE-ADDED EXPORTS IN THE ESTIMATION OF EXPORT DIVERSIFICATION IN ASIA AND THE PACIFIC
}

Pallavi Bajaj, Kristina Baris, Patricia Georgina Gonzales, Christian Regie Jabagat, Janine Elora Lazatin, and Elaine Tan

NO. 650

March 2022
ADB ECONOMICS WORKING PAPER SERIES 


\section{ADB Economics Working Paper Series}

\section{A Case for Value-Added Exports in the Estimation of Export Diversification in Asia and the Pacific}

Pallavi Bajaj, Kristina Baris, Patricia Georgina Gonzales, Christian Regie Jabagat, Janine Elora Lazatin, and Elaine Tan

No. 650 | March 2022
Pallavi Bajaj (pallavibajaj@gmail.com) is a consultant of TCube Consulting LLP and trade specialist at the United Nations Conference on Trade and Development, Geneva, Switzerland. Kristina Baris (kbaris.consultant@adb.org), Patricia Georgina Gonzales (pggonzales.consultant@adb.org), Christian Regie Jabagat (cjabagat.consultant@adb.org), and Janine Elora Lazatin (jlazatin1.consultant@adb.org) are consultants of the Statistical Data and Innovation Unit (SDIU), Asian Development Bank (ADB). Elaine Tan (estan@adb.org) is advisor at the Office of the Chief Economist and Director General, and head of SDIU, Economic Research and Regional Cooperation Department, ADB.

The authors are grateful for the contributions and inputs of Janine De Vera, Mahinthan Mariasingham, Reizle Platitas, and Marcus San Pedro. 
(C) 2022 Asian Development Bank 6 ADB Avenue, Mandaluyong City, 1550 Metro Manila, Philippines

Tel +632 8632 4444; Fax +63286362444

www.adb.org

Some rights reserved. Published in 2022.

ISSN 2313-6537 (print), 2313-6545 (electronic)

Publication Stock No. WPS220068-2

DOI: http://dx.doi.org/10.22617/WPS220068-2

The views expressed in this publication are those of the authors and do not necessarily reflect the views and policies of the Asian Development Bank (ADB) or its Board of Governors or the governments they represent.

ADB does not guarantee the accuracy of the data included in this publication and accepts no responsibility for any consequence of their use. The mention of specific companies or products of manufacturers does not imply that they are endorsed or recommended by ADB in preference to others of a similar nature that are not mentioned.

By making any designation of or reference to a particular territory or geographic area, or by using the term "country" in this document, $A D B$ does not intend to make any judgments as to the legal or other status of any territory or area.

This work is available under the Creative Commons Attribution 3.0 IGO license (CC BY 3.0 IGO)

https://creativecommons.org/licenses/by/3.0/igo/. By using the content of this publication, you agree to be bound by the terms of this license. For attribution, translations, adaptations, and permissions, please read the provisions and terms of use at https://www.adb.org/terms-use\#openaccess.

This CC license does not apply to non-ADB copyright materials in this publication. If the material is attributed to another source, please contact the copyright owner or publisher of that source for permission to reproduce it. $\mathrm{ADB}$ cannot be held liable for any claims that arise as a result of your use of the material.

Please contact pubsmarketing@adb.org if you have questions or comments with respect to content, or if you wish to obtain copyright permission for your intended use that does not fall within these terms, or for permission to use the ADB logo.

Corrigenda to ADB publications may be found at http://www.adb.org/publications/corrigenda.

Note:

In this publication, “\$” refers to United States dollars.

The ADB Economics Working Paper Series presents data, information, and/or findings from ongoing research and studies to encourage exchange of ideas and to elicit comment and feedback about development issues in Asia and the Pacific. Since papers in this series are intended for quick and easy dissemination, the content may or may not be fully edited and may later be modified for final publication. 


\section{CONTENTS}

FIGURES AND BOXES

iv

ABSTRACT V v v v v v v v v

$\begin{array}{ll}\text { I. INTRODUCTION } & 1\end{array}$

II. EXPORT DIVERSIFICATION AND ECONOMIC GROWTH: THE LITERATURE 2

III. METHODOLOGY FOR MEASURING EXPORT DIVERSIFICATION 4

A. Choice of Indicators $\quad 4$

B. Construction of the Herfindahl-Hirschman Index using Value-Added Exports 6 Based on Forward Linkages

C. Herfindahl-Hirschman Index Gross Exports versus Herfindahl-Hirschman Index 7 Value-Added Exports

IV. TRENDS AND PATTERNS IN EXPORT DIVERSIFICATION FOR ECONOMIES 10 IN ASIA AND THE PACIFIC (2007-2018)

V. RELATIONSHIP WITH ECONOMIC GROWTH 19

$\begin{array}{lr}\text { VI. CONCLUSIONS } & 23\end{array}$

$\begin{array}{lr}\text { REFERENCES } & 25\end{array}$ 


\section{FIGURES AND BOXES}

\section{FIGURES}

1 Average Herfindahl-Hirschman Index of Selected Economies in Asia and the Pacific, 2007-2018

2 Change in Average Herfindahl-Hirschman Index, 2007 versus 2018

3 Economy Classifications Based on Herfindahl-Hirschman Index

4 Herfindahl-Hirschman Index Comparisons using Gross and Value-Added Exports, Category 1

5 Herfindahl-Hirschman Index Comparisons using Gross and Value-Added Exports, Category 2

6 Herfindahl-Hirschman Index Comparisons using Gross and Value-Added Exports, Category 3, Mining and Quarrying Economies

7 Herfindahl-Hirschman Index Comparisons using Gross and Value-Added Exports, Category 3, Medium- to High-Technology Manufacturing Economies

8 Herfindahl-Hirschman Index Comparisons using Gross and Value-Added Exports, Category 3, Textile and Textile Products Economies

9 Herfindahl-Hirschman Index Comparisons using Gross and Value-Added Exports, Category 3, Business Services Economies

10 Relationship between Gross Domestic Product and Herfindahl-Hirschman Index of Selected Economies in Asia and the Pacific, 2007-2018

11 Relationship between Gross Domestic Product and Herfindahl-Hirschman Index of Selected Economies in Asia and the Pacific by Income Level, 2007-2018

12 Relationship between Gross Domestic Product and Differences in Herfindahl-Hirschman Index Types of Selected Economies in Asia and the Pacific, 2007-2018

\section{BOXES}

1 Theil Concentration Index and Gini Index 5

2 Herfindahl-Hirschman Index 6 


\begin{abstract}
Export diversification, or the breadth of exports of an economy, is increasingly seen as a means of accelerating economic growth, mitigating instability due to price, demand, and exchange rate fluctuations, and stabilizing earnings from exports in the long run. As economies integrate into global and regional value chains, the new fragmented production structures may not be adequately reflected in diversification measurements based on gross exports. This paper develops a new indicator of export diversification based on value added in sectors contributing to exports. For most Asia and the Pacific economies, the gross exports approach underestimates export diversification compared to the valueadded approach. Analyzing the trends suggests a strong case for the latter approach to complement the more traditional approach. The relationship between export diversification and growth is complex and is dependent on the diversification indicator and varies by income levels. One general finding is that divergence between diversification in exporting sectors and in sectors contributing to exports narrowed as income levels of economies increased.
\end{abstract}

Keywords: export, value added, diversification, global value chains

JEL codes: C82, F10, F43, F63 


\section{INTRODUCTION}

Export diversification, defined as the breadth of the composition of an economy's export basket, is increasingly seen as a means of accelerating economic growth, mitigating instability due to price, demand, and exchange rate fluctuations, and stabilizing export earnings in the long run. While there is generally a consensus on the benefits of diversification and its ability to contribute to revenues and the stability of economic growth by hedging against price and demand volatilities, the economic literature is divided on the specifics of the interplay between export diversification and economic growth.

A growing section of the economic literature argues that early in their growth journey, economies diversify their commodity (product) and sector export structures to increase export revenues toward higher economic growth. For example, de Piñeres, Amin, and Ferrantino (2000) assess the relationship between export diversification and economic growth and find in favor of export diversification for growth. Cadot, Carrere, and Strauss-Kahn (2011) take forward the work of Imbs and Wacziarg (2003), extending it to exports based on a similar assessment by Klinger and Lederman (2004), and likewise find a hump-shaped relationship between economic growth and export diversification. Other studies such as Acemoglu and Zilibotti (1997) find the opposite trend for developing economies.

In an increasingly connected global economy with deepening digitalization, accounting for value creation at each stage within global value chains enables us to quantify the full extent of export diversification from a production perspective, the evolving and often more complex production structures within trading economies, and the backward and forward linkages in trade. This, in turn, will shed light on sectoral value-added contributions to export diversification and, more broadly, their role in economic growth.

Hence, it is important to account for all factors that impact production structures when estimating the relationship between export diversification and growth. Basing this assessment on only gross exports in measuring export diversification may not always provide a comprehensive understanding of these production structures. A better understanding of economic diversification would look at diversification based on both gross exports and value-added production.

Of the more popular and widely used indices or measures of export concentration, including the Theil index, Gini index, and the Herfindahl-Hirschman Index $(\mathrm{HHI})$, the $\mathrm{HHI}$ is the preferred index, owing to its simplicity of calculation among other factors. $\mathrm{HHI}$ is derived as the (weighted) sum of the squares of the share of each sector or product group in the total exports of an economy and represents the breadth of the export basket of an economy across all sectors and products. Traditionally, $\mathrm{HHI}$ is estimated using values of gross exports and ranges between 0 and 1. Relatively low HHI values (close to 0 ) indicate high export diversification, while high $\mathrm{HHI}$ values (close to 1) indicate low export diversification (or similarly, high export concentration).

In this paper we introduce a statistical indicator to estimate $\mathrm{HHI}$ using value-added exports based on forward linkages (VAX_F), ${ }^{1}$ which accounts for the fragmentation of production and the

\footnotetext{
The HHIs for both approaches are computed using sector data for 26 exporting economies in Asia and the Pacific for the years 2007-2018 based on available data from the Asian Development Bank Multiregional Input-Output Table and global value chain indicators.
} 
layered chain of activities that lead to the value added embedded in exports. On the one hand, a gross exports approach gives a picture of how total value added from the economy is exported. On the other hand, the value-added approach provides a closer link to the underlying economic structures and productive capacities of exporting economies while avoiding the double-counting typical in the valuation of gross exports.

The analysis of export diversification using sector-level data accounts for the fact that each sector of production and export comprises multiple subsectors and activities, with potential overlapping of similar products and processes, even at a more granular level. Therefore, aggregating data by sector can reveal a more comprehensive picture of the structure of the export portfolio of an economy. Incorporating VAX_F at the sector level into the estimation of $\mathrm{HHI}$ also provides a more comprehensive picture of the interlinkages between sectors in the exporting economy and the contribution of each sector, both directly and indirectly, to gross exports. With rapid technological advances, the near-global reach of e-commerce, and regional and global value chains, as well as increased participation in preferential trade agreements and deals, it would not be unusual to observe increasingly less uniform production and supply chains within economies contributing to their export baskets. In addition, these evolving dynamics will also impact the diversification-growth relationship and potentially yield new findings in the future as digitalization grows in importance.

Using the interaction of both $\mathrm{HHI}$ measurements and log of gross domestic product (GDP) per capita, this paper will explore the relationship between export diversification and growth following the conceptual framework provided by Imbs and Wacziarg (2003) and taken forward into exports by Cadot, Carrere, and Strauss-Kahn (2011).

Section I of this paper explores the existing literature on export diversification and its relationship to economic growth. Section II addresses the methodology of estimation of export diversification for the rest of the paper, explaining the choice of the $\mathrm{HHI}$ as the appropriate index of export diversification, the theoretical basis of using value-added exports in the estimation of the $\mathrm{HHI}$, and the framework adopted for the decomposition of exports to arrive at the two estimates of the HHI. Section III examines the evolution of export diversification for 26 economies in Asia and the Pacific during 2007-2018 using sector-level gross exports and VAX_F data. Section IV examines the relationship between each of these indices ( $\mathrm{HHI}$ based on gross exports and value-added exports) with economic growth for these economies during the period under review. The concluding section $\mathrm{V}$ summarizes the analyses and makes a case for the complementary use of value-added exports in estimating export diversification.

\section{EXPORT DIVERSIFICATION AND ECONOMIC GROWTH: THE LITERATURE}

Traditional trade theories based on resource endowments posit that economies should identify their absolute or relative comparative advantage and specialize in those sectors. However, over time, economists have progressively explored the relationship between economic diversification and growth. Romer (1990) and Krugman (1980) are early studies assessing the diversification of economic activities. These theories have assumptions pertaining to market size, market dynamics, competition, factor endowments, factor movements, the resultant factor-price equalization, and opportunity costs. 
Most of these assumptions have evolved with increasing trade, globalization and, more recently, the advent of digital technologies in trade and value chains in the production and delivery of goods and services. To this extent, the role of diversification and specialization needs to be reconsidered.

Several studies have shown that the more diversified the export portfolio, the better hedged an economy is against economic shocks and volatility in price and demand. This fosters an environment for long-term resilient economic growth by building on productive economic transformation through increased competitiveness across a wider spectrum of products and sectors as well as enhanced product sophistication and contributes to the wider macroeconomic goal of a healthy balance of payments.

With technological innovation, the rapid growth of regional and global value chains, and the increasing study of services embedded in manufacturing, the dynamics of the global market have evolved and movement of factors has taken on a new meaning, shifting from the assumptions of traditional and erstwhile economic theory. Several studies have attempted to assess the relationship between economic growth and export diversification. Acemoglu and Zilibotti (1997), for example, suggest that the initial concentration at low levels of development and increased diversification at higher levels of development may be because of structural and institutional factors, as well as technological limitations in economies' low levels of development impeding the scope for export diversification, thereby underscoring the role of endogenous investors in higher-risk sectors.

At the same time, Imbs and Wacziarg (2003), in their seminal study of the stages of diversification predicated on the Herfindahl-Hirschman Index $(\mathrm{HHI})$, noted a U-shaped relationship between economic growth (measured using log of GDP per capita as an estimate of income) and sector specialization or concentration of economic activity (or a hump-shaped relationship between economic growth and sectoral diversification).

Taking this forward into exports, Hausmann, Hwang, and Rodrik (2006) map the export basket of an economy against its productivity levels and find a higher growth rate of economies that produce (export) high-productivity goods. Hausmann and Klinger (2006) study the relationship between structural transformation and economic growth, noting that increased export diversification enables the exporting economy to increase competitiveness, produce and export more complex products, and achieve higher, more resilient economic growth. Hesse (2008), using the HHI added to a basic augmented Solow growth regression, finds empirical evidence of the positive impact of export diversification on income per capita, arguing that this impact is possibly nonlinear in that developing economies benefit more from export diversification, whereas more developed economies can see a more substantive positive impact on economic growth with greater specialization.

Cadot, Carrere, and Strauss-Kahn (2011), based on the work of Imbs and Wacziarg (2003) and Klinger and Lederman (2004), which also uses the Hausman and Rodrik (2003) framework, use the Herfindahl, Theil, and Gini indices to study export diversification. Cadot, Carrere, and Strauss-Kahn (2011) found an inverse U-shaped relationship between economic growth and export diversification, indicating that as economies grow and income increases, they grow with increased diversification. Beyond a point, further growth is driven by the intensive margin (i.e. exporting more of the same goods). Similarly, for economies inside their technological frontier, widening export baskets leads to faster growth (Agosin 2007).

However, the relationship between export diversification and economic growth is more complex with global value chains. More recently, the coronavirus disease (COVID-19) pandemic has slowed economic activity, most prominently impacting manufacturing activity and trade between 
nations. On the one hand, this has caused economists and national governments to rethink global supply chains and underscored the benefits of export diversification in building back more resilient economies supported by sustainable economic growth. On the other hand, the restructured value chains and increasingly digital nature of trade and services embedded in manufacturing, have reset this relationship for some economies.

\section{METHODOLOGY FOR MEASURING EXPORT DIVERSIFICATION}

The inverse of economic diversification is export concentration. The most widely used indices to measure this are the Theil index, the Gini index, and the Herfindahl-Hirschman Index (HHI). While the Gini index (Box 1) and the HHI (Box 2) measure the absolute specialization of economies, the Theil index (also in Box 1) measures their economic structures based on a reference group of sectors or industries.

Cadot, Carrere, and Strauss-Kahn (2011) used the Theil, Gini, and HHI indices to assess the factors behind the $U$-shaped relationship between income and export diversification, noting that reconcentration after a certain level of economic growth occurred at the extensive margin. While Theil's index is one of the only decomposable indices of concentration, it can be difficult to calculate and does not always accommodate all cases fully. As Palan (2010) notes, when accounting for industries or sectors with complete specialization, the Theil index tends to be negative, and when accounting for industries or sectors with entities of negligible size, it tends toward infinity.

\section{A. Choice of Indicators}

The Herfindahl-Hirschman Index (Box 2) measures the degree of concentration of exports by export lines and markets, assessing the degree to which the exports of an economy are dependent on specific sectors, products or trading partners. A higher $\mathrm{HHI}(\mathrm{HHI} \rightarrow 1)$, therefore, indicates more export concentration, whereas a lower $\mathrm{HHI}(\mathrm{HHI} \rightarrow 0)$ indicates export diversification. In the extreme case, where the exports of an economy depend entirely on a single product or sector, the $\mathrm{HHI}$ assumes a value equal to unity (or a value of 1 ).

Similarly, Adajar, Berndt, and Conti (2019) map the HHI against other comparable proposed measures, including mathematical generalizations of the $\mathrm{HHI}$, and account for aspects of computation and interpretability. They conclude that concentration measures that account for both variability or relative inequality and absolute population size, such as the $\mathrm{HHI}$ and the closely related Rosenbluth/Hall-Tideman (RHT), are preferable estimators. 


\section{Box 1: Theil Concentration Index and Gini Index}

The Theil index uses a log operator to measure the level of export diversification which makes it sensitive to the bottom of distribution. Following Ugarte (2014), its basic form is given as:

$$
T=\frac{1}{N} \sum_{n=1}^{N}\left(\frac{S_{i}^{r}}{S}\right) \times \log \left(\frac{S_{i}^{r}}{S}\right)=\frac{1}{N \bar{S}}\left(\sum_{n=1}^{N} S_{i} \times \log S_{i}^{r}\right)-\log (\bar{S})
$$

where $\overline{\mathrm{S}}$ is the average share of value added, namely $\frac{1}{N}$.

\section{Normalization}

$$
\bar{T}=1-\exp (-T)
$$

The Theil index is normalized to ensure its values range from 0 to 1, with values increasing with the degree of concentration. Unlike the Theil index, the Gini index is more sensitive to the middle of the distribution because it takes the sum of cumulative sector shares. It is defined as:

$$
G=1-\frac{1}{N} \sum_{n=1}^{N}\left(S_{i-1}^{r}+S_{i}^{r}\right)
$$

where $S_{i}^{r}$ is the cumulative share of gross output, exports or value added of sector $i$ in the economy $r$ after ordering the value-added shares in increasing order; $N$ is the number of sectors in economy $r$. It ranges between 0 and 1, where 0 implies a homogenously diversified economy wherein all sectors have a perfectly equal share of output, exports or value added to the total economy and 1 implies an extremely concentrated economy with only one sector. The Gini index is more sensitive to the middle portion of the distribution.

Source: Cristian Ugarte. 2014. "Weak Links and Diversification." Policy Issues in International Trade and Commodities Research Study Series No. 67. United Nations Conference on Trade and Development, Geneva.

The $\mathrm{HHI}$ is the simplest, most robust and comprehensive estimate of export diversification and is less complicated compared to the Gini index, which also measures absolute specialization. In addition, it has been observed that absolute measures such as the $\mathrm{HHI}$ are considered superior to relative measures in that they account for exports from new product groups and for product shares in addition to concentration ratios. While the $\mathrm{HHI}$ is not decomposable, calculating $\mathrm{HHI}$ as a measure of diversification allows for decomposition into intersectoral and inter-industry $\mathrm{HHI}$. Due to the advantages of the $\mathrm{HHI}$, this paper adopts its conceptual framework to derive diversification measurements for sectors contributing to exports. The indicators follow the principle of valuation adopted by the $\mathrm{HHI}$ and are elaborated in Box 2. 


\section{Box 2: Herfindahl-Hirschman Index}

The Herfindahl-Hirschman Index $(\mathrm{HHI})$ is a formal measure of export concentration or the degree to which an economy's export basket is dependent on specific products or markets. It is calculated by squaring the shares of each sector or product group in the total exports of the economy, and taking the sum of the squares:

$$
H=\sum_{n=1}^{N}\left(S_{i}^{r}\right)^{2}
$$

and the normalized $\mathrm{HHI}$ is estimated as:

$$
H=\frac{\sum_{n=1}^{N}\left(S_{i}^{r}\right)^{2}-\frac{1}{N}}{1-\frac{1}{N}}
$$

where $S_{i}^{r}$ is the share of gross output, exports or value added of sector $i$ in the economy $r . N$ is the number of sectors in economy $r$. The index is most sensitive to sectors or product groups that comprise a large share of an economy's export basket. The index values range between 0 and 1 , where 0 implies a homogenously diversified economy wherein all sectors have a perfectly equal share of output, exports or value added to the total economy and $1 \mathrm{implies}$ an extremely concentrated economy with only one sector.

Source: Cristian Ugarte. 2014. "Weak Links and Diversification." Policy Issues in International Trade and Commodities Research Study Series No. 67. United Nations Conference on Trade and Development, Geneva.

\section{B. Construction of the Herfindahl-Hirschman Index using Value-Added Exports Based on Forward Linkages}

To estimate $\mathrm{HHI}$ based on sectoral VAX_F and gross exports, this paper uses the ADB Multiregional Input-Output Table (MRIOT) and applies the Wang, Wei, and Zhu (2013) framework (also referred commonly to as the WWZ methodology) to estimate VAX_F. VAX_F is an estimate of the domestic value added (DVA) generated in producing goods and services that satisfy foreign final demand, including indirect value-added exports. The classification of sectors is in line with the World Input-Output Tables (WIOT).

A sector perspective of export diversification has not been studied much in the literature but can supplement the more conventional product-perspective assessment. Since products and processes within sectors feed into and are integrated with each other, a consolidated view of a sector can simplify the analysis. Furthermore, with the increasing significance of value chains in the production and delivery of goods and services, the use of value-added exports to estimate export data and export diversification indices provides a complementary investigation of trends at a sector level. This treatment is aligned with the typically sector-based consideration of economic structures and sector-specific interventions in both private and public spheres.

Realistically, meaningful export diversification and the resulting structural transformation entails not only expanding or improving the production of certain commodities, but more importantly, 
the overall upgrading of sector capacities to allow exporting economies to engage in more diverse, competitive and higher value-added activities.

\section{Herfindahl-Hirschman Index Gross Exports versus Herfindahl-Hirschman Index Value-Added Exports}

The conventional estimation of exports in gross terms provides an insight into the export basket of the economy as a whole. In this regard, an assessment of exports and export diversification on gross exports is desirable in an analysis of the evolution of trade and trade-related statistics. However, with the growing reach of global value chains and the resulting use of foreign intermediate inputs in the production of goods for exports, goods often cross borders several times, with each process adding value to intermediate inputs toward the final output. In a similar vein, services embedded in the production of manufactured goods also add value to the final output at various stages. The conventional method for estimating trade data using gross exports, therefore, includes both the final product and any intermediate inputs, resulting in double counting of intermediate inputs and an overestimation or underestimation of the domestic value added in exports. Similarly, the indirect value added by support sectors is not captured by gross exports.

$\mathrm{HHI}$ estimated on gross exports ( $\mathrm{HHI}$ GE) masks the complex chain of activities within an economy that result in value added embedded in gross exports and does not account for the indirect value-added exports of a sector in the output of other sectors. For example, the increased role of services in manufacturing, specifically business services, are often underestimated or not captured at all in the gross exports of service sectors but are included in the gross exports of the direct exporting sectors. Using the share of value added based on forward linkages in exports could reassign the value added of such embedded services to the sector where they originated. As UNCTAD (n.d.) notes, "there is substantial value added of services, which is not captured in this data, incorporated in goods exports, from services intermediate inputs and services bundled with goods" In addition, $\mathrm{HHI}$ estimated using gross exports would also include the component of foreign value added embedded in the gross exports from that sector. This would risk skewing the estimated export diversification.

A more comprehensive assessment of export diversification, therefore, requires further decomposition of gross exports to allow for a deeper analysis of the data. To this end, following the WWZ framework, a sector's gross exports can be decomposed into various components, including domestic value added based on forward linkages or VAX_F. HHI can then be estimated using gross exports and VAX_F separately and the two estimates can be read in parallel for a detailed understanding of the layered production processes and resulting export composition.

Figure 1 maps average HHI GE against HHI VAX_F for 26 economies in Asia and the Pacific for 2007-2018. It indicates the difference between $\mathrm{HHI}$ values in each case. For most of these economies, $\mathrm{HHI}$ GE and HHI VAX_F differ. Therefore, a more complete understanding of diversification will have to look at the channels through which products and value added are exported (sectoral gross exports) and the local production structure involved in the generation of value added embedded in gross exports (sectoral VAX_F).

Consequently, this paper notes that the use of exports in value added terms, especially VAX_F, could unmask the various layers of the production processes within an economy. VAX_F differs in absolute value from gross exports as it includes, according to Wang, Wei, and Zhu (2013), the "indirect value added contributed to other sectors' gross exports and indirect trade via third countries." 


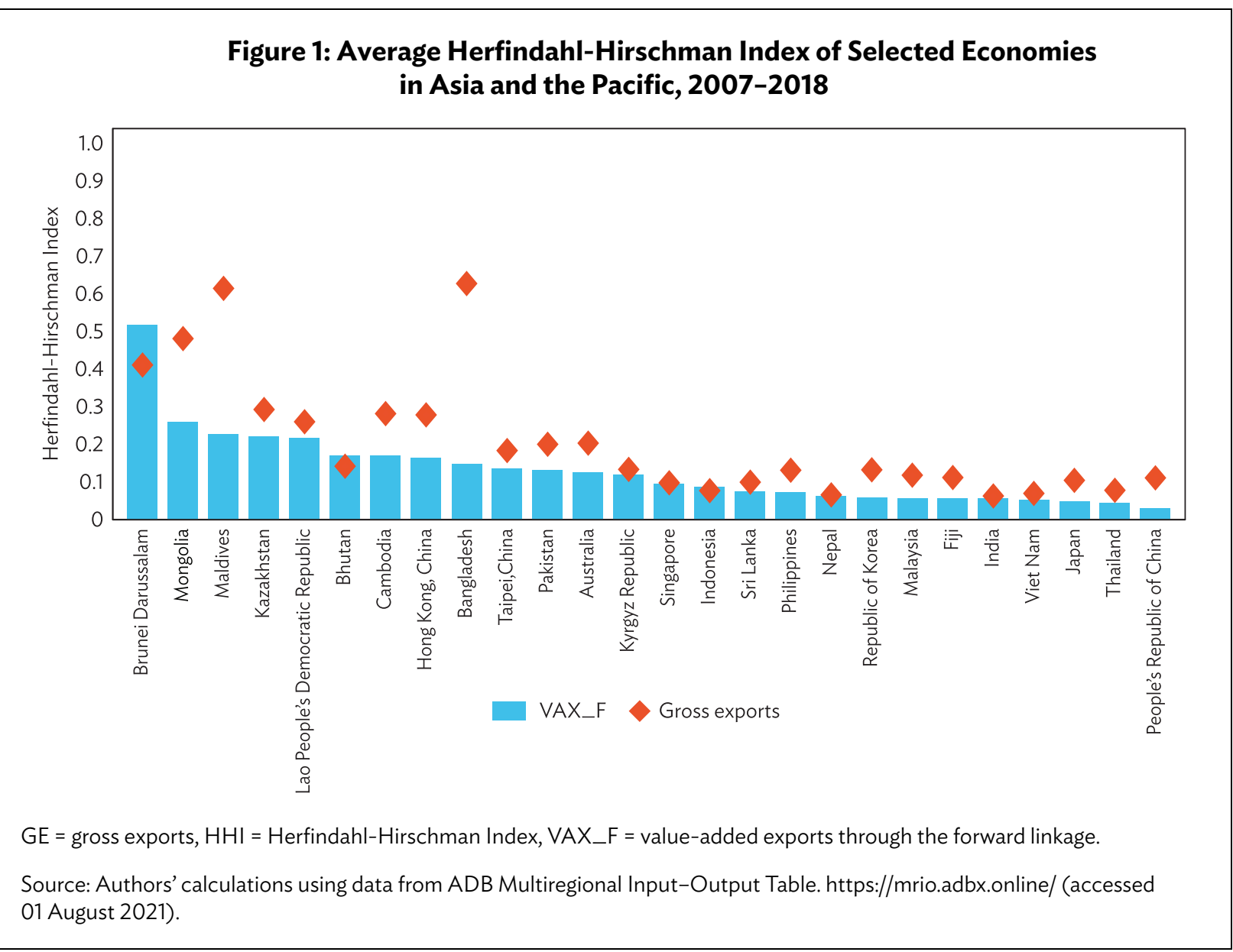

Moreover, the use of value-added exports eliminates double counting and foreign value added in the valuation of exports and assigns value added inputs to originating sectors rather than direct exporting sectors. Using $\mathrm{VAX} \_\mathrm{F}$ in the estimation of $\mathrm{HHI}$ adds an additional layer of information on direct and indirect value added to exports. While HHI GE would also account for foreign value added, which can overestimate actual production activity within the economy, HHI VAX_F would not include foreign value added but will include the indirect exports from these sectors.

HHIs and their changes between 2007 and 2018 also differ significantly, depending on the approach used to estimate diversification. This is shown in Figure 2, which depicts the change in $\mathrm{HHI}$ GE and HHI VAX_F between 2007 to 2018. For economies such as Indonesia, Malaysia, Mongolia, Pakistan, the Philippines, the People's Republic of China, and Singapore, for example, the evolution of export diversification between the two years diverges. This indicates that using gross exports alone in estimating diversification and looking at trends may not always fully account for the complexities of fragmented production as economies integrate into the global economy and value chains. 
Figure 2: Change in Average Herfindahl-Hirschman Index, 2007 versus 2018

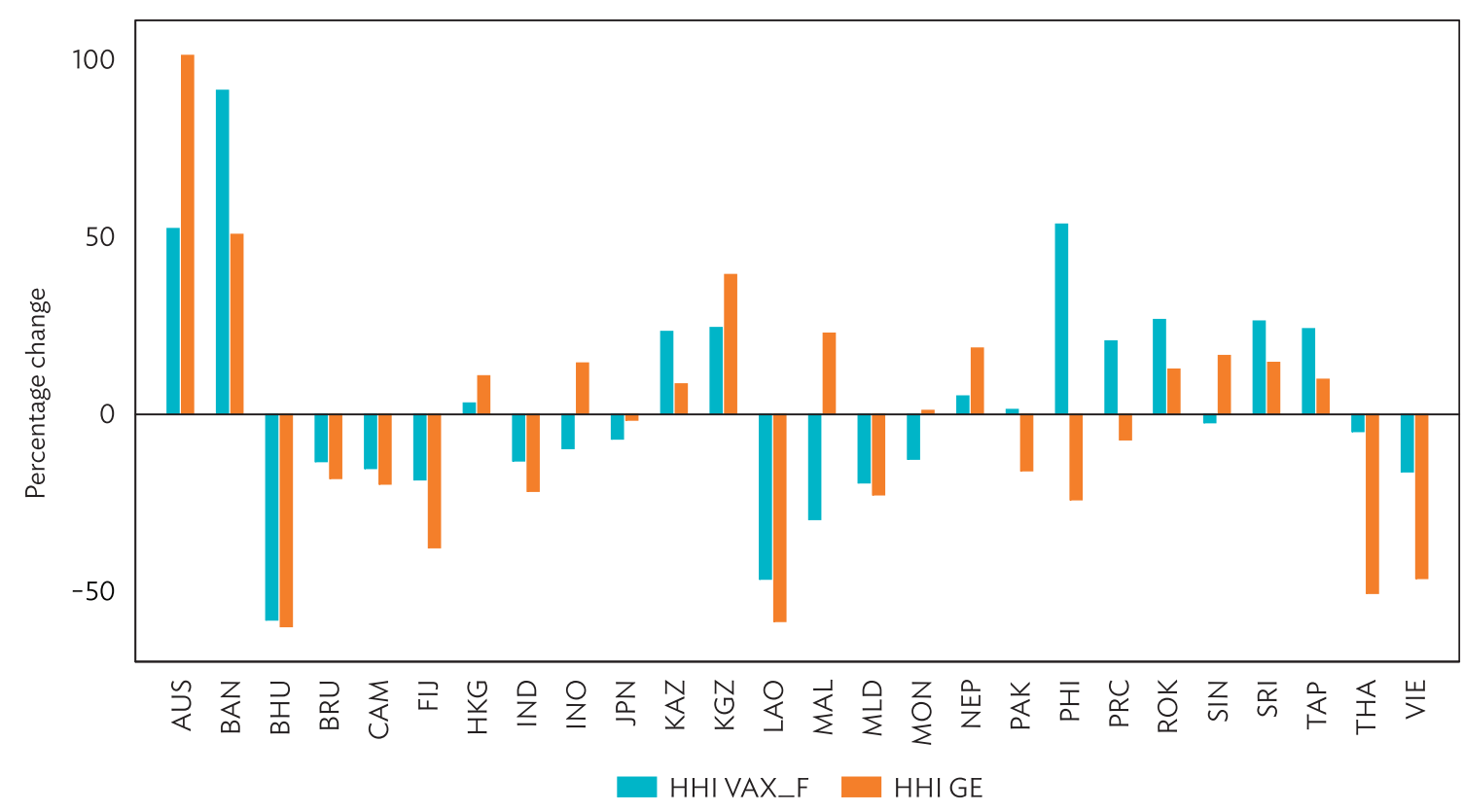

AUS = Australia; $\mathrm{BAN}=$ Bangladesh; $\mathrm{BHU}=$ Bhutan; $\mathrm{BRU}=$ Brunei Darussalam; $\mathrm{CAM}=$ Cambodia; FIJ = Fiji; $\mathrm{GE}=$ gross exports; $\mathrm{HHI}=$ Herfindahl-Hirschman Index; HKG = Hong Kong, China; IND = India; INO = Indonesia; JPN = Japan; KAZ = Kazakhstan; KGZ = Kyrgyz Republic; LAO = Lao People's Democratic Republic; MAL = Malaysia; MLD = Maldives; MON = Mongolia; NEP = Nepal; PAK = Pakistan; $\mathrm{PHI}=$ Philippines; PRC = People's Republic of China; ROK = Republic of Korea; SIN = Singapore; SRI = Sri Lanka; TAP = Taipei,China; THA = Thailand; VAX_F = value-added exports through the forward linkage; VIE = Viet Nam.

Source: Authors' calculations using data from ADB Multiregional Input-Output Table. https://mrio.adbx.online/ (accessed 01 August 2021).

Section III explores these differences and shows that in most economies, the trends of HHI GE and HHI VAX_F are determined by the key or dominant sectors in exports and movements of their shares across time. It is observed that reading trends in HHI VAX_F in parallel with HHI GE better explains the evolution of export diversification for these economies by accounting for the fragmentation of production and the layered chain of activities that lead to the value added embedded in exports. This provides a closer link to the underlying economic structures and productive capacities of exporting economies, thereby contributing to better-informed policy decisions. 


\section{TRENDS AND PATTERNS IN EXPORT DIVERSIFICATION FOR ECONOMIES IN ASIA AND THE PACIFIC (2007-2018)}

Economies can be grouped using the difference in their 2007-2018 average HHI GE and HHI VAX_F. Figure 3 shows this schema and enumerates the economies falling under each category.

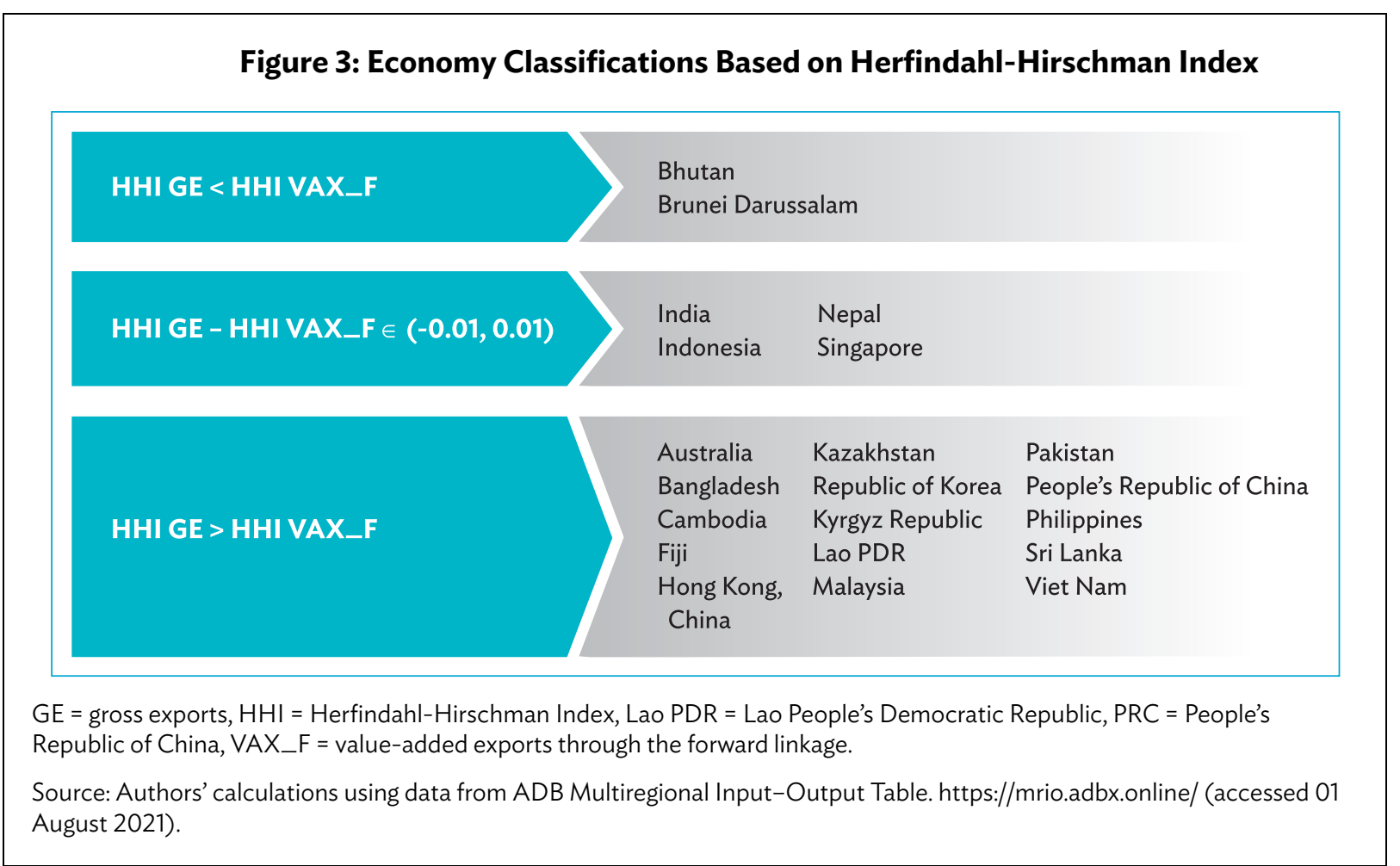

Figures 4 to 9 break down a facile assessment of the evolution of HHI GE and HHI VAX_F for each of the 26 economies in Asia and the Pacific included in the analysis. Economies are first grouped based on the schema in Figure 3 and then the evolution of export diversification is discussed for one or two of the economies to highlight how a discussion of diversification from both perspectives can give a better understanding of economies' participation in international trade and their underlying production complexities. $^{2}$

Category 1: $\mathrm{HHI}$ GE < HHI VAX_F. An economy is said to be more diversified in gross exports whenever HHI GE is less than HHI VAX_F, as in the case of Bhutan and Brunei Darussalam (Figure 4). For these two economies, the contributions of each of their largest sectors to VAX_F are

2 Due to space constraints, we have excluded discussions for most economies and have highlighted a few as illustrative examples. 
larger than their contributions to gross exports. Moreover, foreign value added plays a smaller role in these economies' exports. ${ }^{3}$

Bhutan and Brunei Darussalam show a comparative advantage in the primary sector, implying that the share of VAX_F from the primary sector in the economy's total VAX_F exceeds that of the world average. ${ }^{4}$ Because the primary sector is generally composed of extractive industries relying on natural endowments, foreign value added in the gross exports of these sectors is expected to be low. In Bhutan, agriculture, hunting, forestry and fishing is the second largest sector next to electricity, gas and water supply, which also relies on natural endowments for production. ${ }^{5}$ In Brunei Darussalam, the main exporting sector is mining and quarrying. The economy also appears to have built a whole chain around this sector, where sector outputs serve as inputs to other sectors' exports.

\section{Figure 4: Herfindahl-Hirschman Index Comparisons using Gross and Value-Added Exports, Category 1}

(a) Bhutan

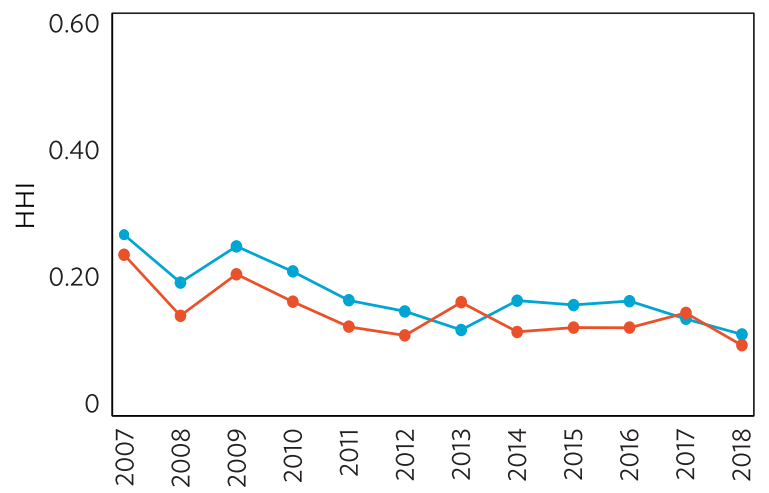

(b) Brunei Darussalam

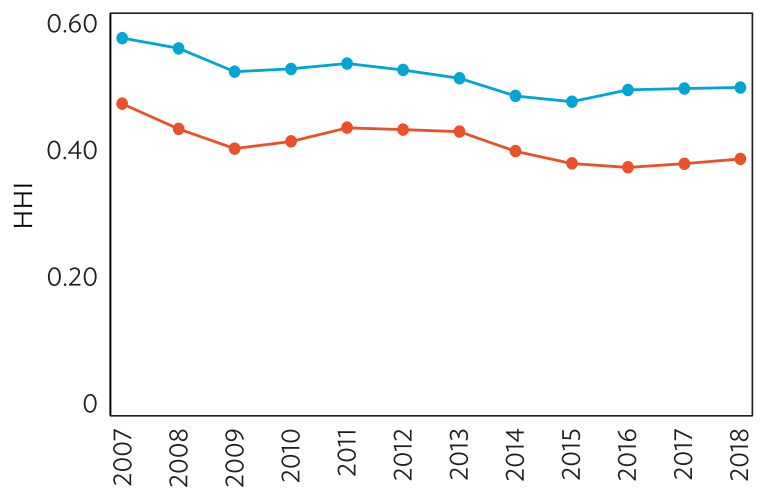

$\rightarrow$ HHIVAX_F $\rightarrow$ HHI Gross exports

$\mathrm{GE}=$ gross exports, $\mathrm{HHI}=$ Herfindahl-Hirschman Index, $\mathrm{VAX} \_\mathrm{F}=$ value-added exports through the forward linkage.

Source: Authors' calculations using data from ADB Multiregional Input-Output Table. https://mrio.adbx.online/ (accessed 01 August 2021).

Bhutan (Figure 4a) shows consistently increasing export diversification starting in 2009, with the only notable exceptions in 2013 and 2017 when there was an increase in diversification on VAX_F and a decrease in diversification on gross exports. The sector contribution in both gross exports of electricity, gas and water supply (largely to India) and agriculture, forestry, hunting and fishing, the key exporting sectors, declined consistently throughout the period under review. In gross exports, the contribution of mining and quarrying, hotels and restaurants, inland transport, air transport, and wholesale trade and commission trade increased from 2007 to 2018.

3 The average foreign value-added share in gross exports is 12 percent for Bhutan and 7 percent for Brunei Darussalam. These values fall below the $25^{\text {th }}$ percentile of the distribution of the 2007-2018 average foreign value-added shares for the 62 economies and the rest of the world in the ADB MRIOTs.

4 Revealed comparative advantage is computed using VAX_F instead of gross exports as in Wang, Wei, and Zhu (2013).

5 Hydropower makes up the bulk of Bhutan's energy production and exports. 
On average, HHI VAX_F was higher than HHI GE in Bhutan, which partly accounts for the fact that Bhutan's main exporting sectors rely on natural resources, needing little value added from other sectors and economies as inputs to export production. Additionally, the main products of Bhutan's agriculture, forestry, hunting and fishing and electricity, gas and water supply sectors serve as important inputs to the export production of other sectors. Thus, it is reasonable to expect that the indirect value-added exports from this sector is large. A comparison of the contributions of the two main exporting sectors to gross exports and VAX_F show that together these two main exporting sectors have higher contributions in VAX_F than in gross exports. In Bhutan's case, gross export tends to understate the importance of electricity, gas and water supply and agriculture, forestry, hunting and fishing in exports production. This is because gross export ignores the value-added contributions of these two upstream sectors in the production of other sectors' exports. However, the difference in HHI GE and HHI VAX_F appears to be decreasing over time. This might reflect the growing contribution of support services and the indirect contribution of other sectors to exports in Bhutan.

Similarly, the resource-rich economy of Brunei Darussalam (Figure 4b) tended toward greater diversification during the period under review, accounted for, in part, by the increasing relative share of coke, refined petroleum and nuclear fuels between 2007-2018 and the relative decline in the sector contribution of the mining and quarrying sector to both gross exports and VAX_F. The oil-rich economy could have also benefited from the increase in the price of oil in the global market, leading to an increase in the share of the coke, refined petroleum and nuclear fuels sector in both gross exports and VAX_F.

As in the case of Bhutan, gross export understates the contribution of mining and quarrying in forward linkages. Despite the declining share of mining and quarrying in gross exports, data shows that the difference in the contribution of the sector in VAX_F versus gross exports has been increasing over time, from 11.4 percent in 2007 to 20 percent in 2018. This is as the coke, refined petroleum and nuclear fuels sector grows in importance in gross exports and VAX_F. Unlike with mining and quarrying, the coke, refined petroleum and nuclear fuels sector makes higher contributions to gross exports than in VAX_F but the difference is of the same absolute magnitude as with mining and quarrying. This reflects the interlinkage of the two main industries in export production, with the coke, refined petroleum and nuclear fuels sector sourcing its inputs from the mining and quarrying sector. This is demonstrated by the change in the components of Brunei Darussalam's product exports from crude oil to refined petroleum over the years. ${ }^{6}$ It must also be noted that the dominance of mining and quarrying far outweighs the contributions of coke, refined petroleum and nuclear fuels in gross exports and VAX_F, which drives the relatively larger negative difference between HHI GE and HHI VAX_F.

Category 2: HHI GE - HHI VAX_F $\in(-0.01,0.01)$. Several economies have HHI GE that are approximately equal to $H_{H}$ VAX_F, implying that they have approximately the same level of diversification from both the gross export and VAX_F perspective (Figure 5). Economies falling into this category include India, Indonesia, Nepal, and Singapore. While these economies' main exports are different from each other, the differences in the average contributions of the two main export sectors of each economy in gross export and VAX_F are never more than 8 percentage points. Moreover, the role of business services in forward linkages is higher than in gross exports. This is in contrast with economies in the first category, where business services contributions to VAX_F are less than or close to their contributions in gross exports. ${ }^{7}$ Except for Indonesia, economies in the second category also

6 See the Observatory of Economic Complexity for more details. https://oec.world/en.

7 The difference between business services contribution to gross exports and VAX_F across years ranges from -0.8 to 7.0 percentage points for economies where HHI GE < HHI VAX_F. For economies where HHI GE are approximately equal to HHI VAX_F, the range is from 5.6 to 20.9 percentage points. 
have revealed comparative advantage in the business services sectors. Thus, business services play a larger role in forward linkages in these economies than gross exports imply.

\section{Figure 5: Herfindahl-Hirschman Index Comparisons using Gross and Value-Added Exports, Category 2}

(a) India

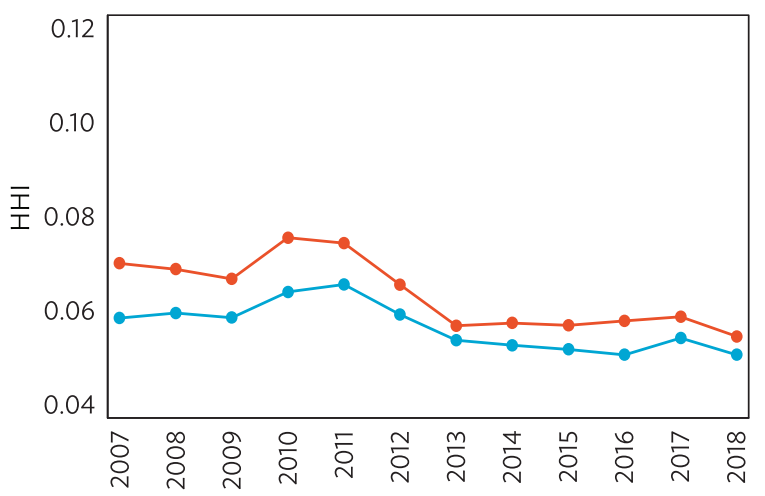

(c) Nepal

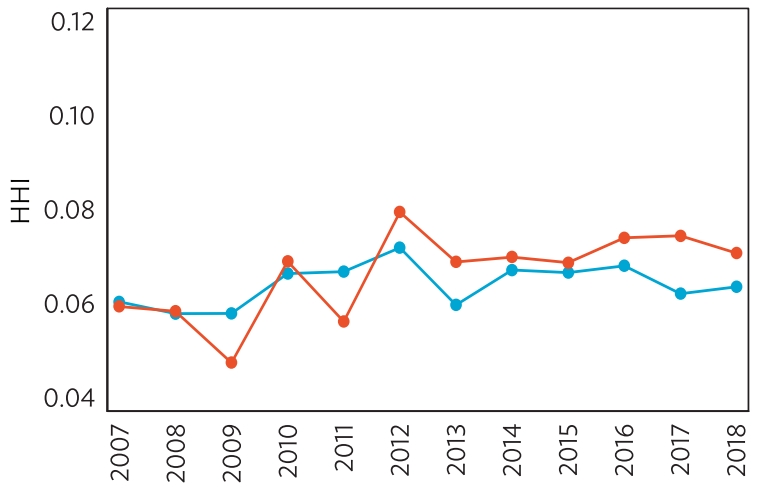

(b) Indonesia

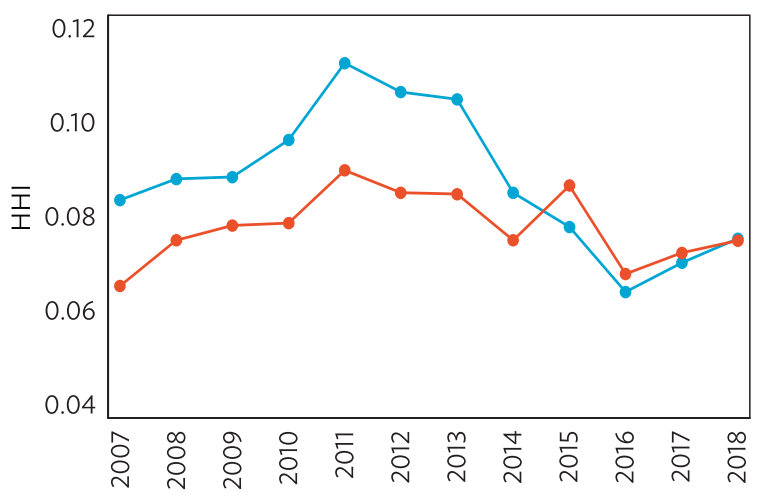

(d) Singapore

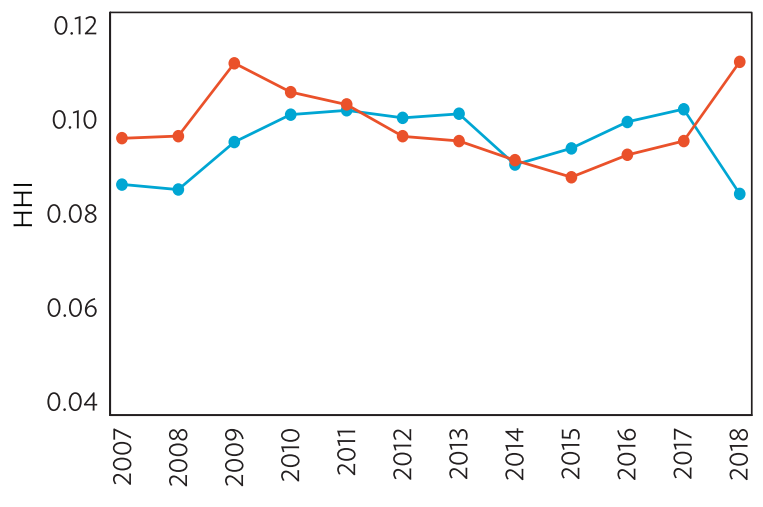

$\rightarrow$ HHIVAX_F $\rightarrow$ HHI Gross exports

$\mathrm{GE}=$ gross exports, $\mathrm{HHI}=$ Herfindahl-Hirschman Index, $V A X \_F=$ value-added exports through the forward linkage.

Source: Authors' calculations using data from ADB Multiregional Input-Output Table. https://mrio.adbx.online/ (accessed 01 August 2021).

We look at two examples in greater detail. The Indian economy (Figure 5a) saw significant export diversification across sectors during the period under review. While the dominant sectors contributing to gross exports and VAX_F remained the same during the period under review, their relative contribution to both gross exports and VAX_F changed between 2007-2018, resulting in the increase in export diversification during this period.

During 2007-2018, the relative significance of textiles and textile products; coke, refined petroleum, and nuclear fuel; chemicals and chemical products; and transport equipment in gross exports have also increased, indicative of India's increased focus on manufacturing exports. The shares of these sectors in gross exports are also significantly higher than their shares in VAX_F. Thus, they play a larger role in gross exports than in VAX_F. Additionally, the foreign value-added shares in the gross 
exports of the coke, refined petroleum, and nuclear fuel and transport equipment sectors are also quite significant but have declined over time, pointing to an initial approach of producing the necessary intermediate inputs at home.

At the same time, among the sectors contributing most to VAX_F, the relative significance of wholesale trade and commission trade, except of motor vehicles and motorcycles and retail trade, repair of household goods increased over this period. Moreover, the shares of these business service sectors are significantly higher in VAX_F than in gross exports. This indicates the increasingly stronger role of business services in exporting activity.

The changing structure of exports explains the declining trends in HHI GE and HHI VAX_F.

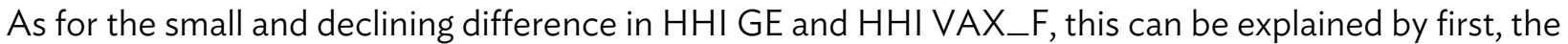
small difference in the contribution of the renting of machinery and equipment and other business activities sector in gross exports and VAX_F and the small proportion of foreign value-added content in the gross exports of the same sector. Secondly, the main manufacturing sectors play a much larger role in gross exports than they do in VAX_F, while business services play a larger role in VAX_F than in gross exports. Thus, the diverging roles of these sectors partly offset each other, creating a small difference in $\mathrm{HHI}$ GE and HHI VAX_F.

According to Figure 5b, export diversification from both perspectives decreased in Indonesia between 2007 and 2011. After this period, the export basket of Indonesia became increasingly diversified across sectors. Starting in 2016, export diversification declined across all estimates of HHI, with $\mathrm{HHI}$ GE moving in a different direction for a few years from HHI VAX_F. Overall, the difference in HHI GE and HHI VAX_F is small and has been on a declining trend since 2012.

Of the economies in this group, Indonesia is a special case. In earlier years, its HHI VAX_F was slightly above its HHI GE until 2015. After 2015, the values converged. This may be partly explained by the dominance of its mining and quarrying sector until 2014. By 2015, its coke, refined petroleum, and nuclear fuel sector dominated with its drastically increased share of gross exports. While there was also a corresponding increase of its coke, refined petroleum, and nuclear fuel sector contribution to VAX_F in 2015, this increase is relatively small at 9 percentage points (pp) compared to its increase in gross exports contribution (18 pp). It also got an increasing VAX_F share in the service sectors including financial intermediation and other manufacturing sectors including transport equipment. Estimating $\mathrm{HHI}$ by gross exports alone also misses the increased value-added contribution of the agriculture, forestry, hunting and fishing sector, which was the second most significant sector in VAX_F to VAX_F during the period under review.

Category 3: HHI GE > HHI VAX_F. The economies in the third group are more diversified from the VAX_F perspective, i.e., HHI GE > HHI VAX_F (Figures 6-9). These economies include Australia; Bangladesh; Cambodia; Fiji; Hong Kong, China; Japan; Kazakhstan; the Lao People's Democratic Republic; Malaysia; Maldives; Mongolia; Pakistan; the People's Republic of China; the Philippines; the Republic of Korea; Sri Lanka; Taipei,China; Thailand; and Viet Nam. The largest exporting sectors in these economies have VAX_F shares in economy-wide VAX_F smaller than gross export shares in economy-wide gross exports.

Among economies where HHI GE > HHI VAX_F, Australia, Kazakhstan, the Lao People's Democratic Republic, and Mongolia have mining and quarrying as their biggest export sector (Figure 6). What makes them different from Brunei Darussalam in the first category is that the main mining and quarrying export products of these economies are in their crude form rather than refined. This partly leads to a larger relative contribution of the sector in gross exports than in VAX_F. In Brunei Darussalam, the mining and quarrying sector appears to be supplying inputs to the coke, refined petroleum, and 
nuclear fuel sector, which is why its relative contribution to gross exports is understated when compared to VAX_F.

\section{Figure 6: Herfindahl-Hirschman Index Comparisons using Gross and Value-Added Exports, Category 3, Mining and Quarrying Economies}

(a) Australia

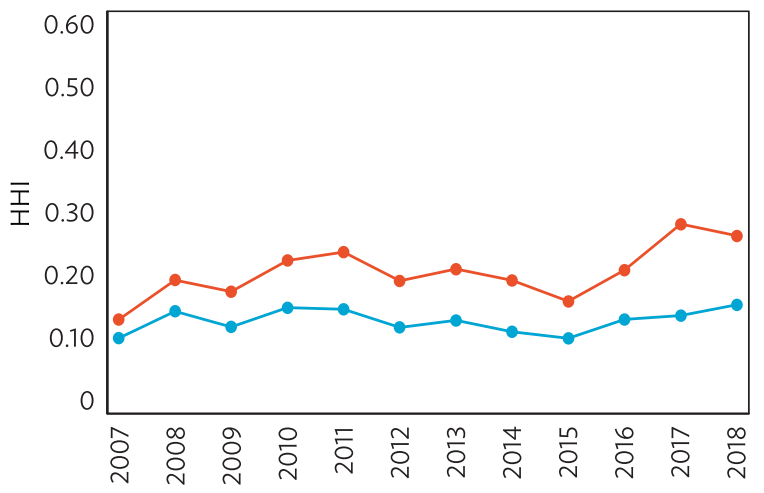

(c) Lao People's Democratic Republic

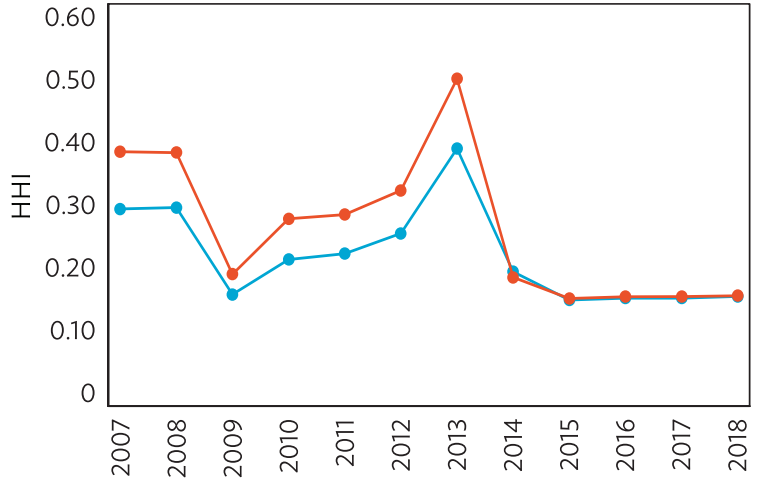

(b) Kazakhstan

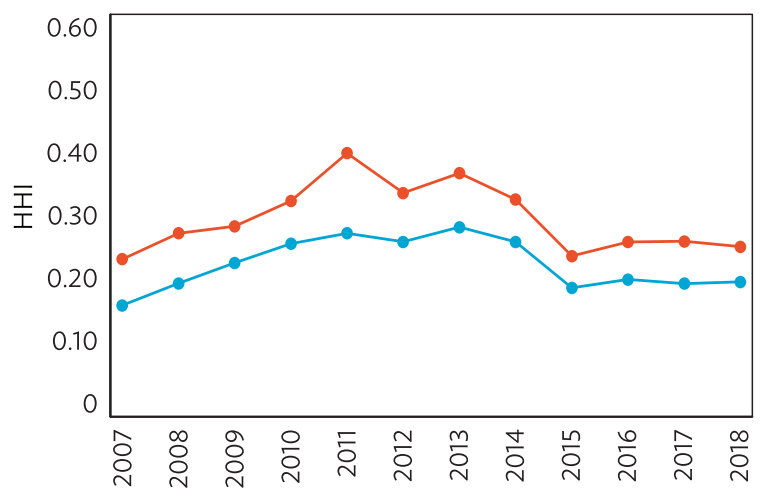

(d) Mongolia

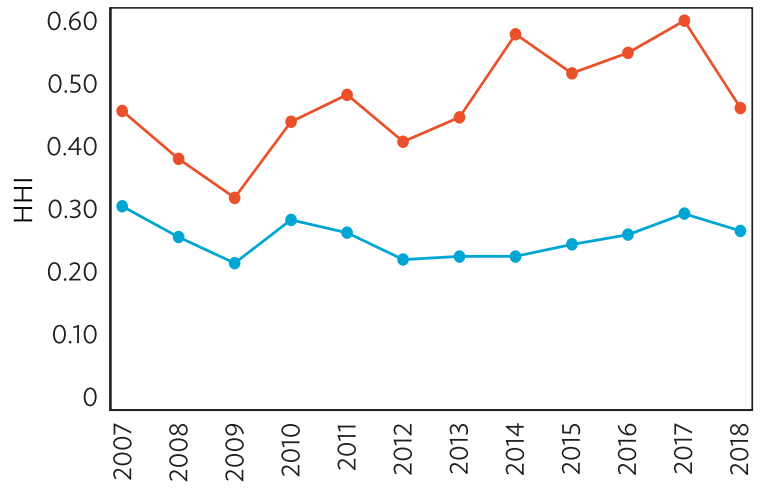

$\rightarrow$ HHIVAX_F $\rightarrow$ HHI Gross exports

$\mathrm{GE}=$ gross exports, $\mathrm{HHI}=$ Herfindahl-Hirschman Index, VAX_F = value-added exports through the forward linkage.

Source: Authors' calculations using data from ADB Multiregional Input-Output Table. https://mrio.adbx.online/ (accessed 01 August 2021).

The next set of economies in the third category are economies where high-technology manufacturing sectors account for the largest share of their exports (Figure 7). In particular, these sectors include electrical and optical equipment, transport equipment, and basic metals and fabricated metals. Economies in this set include Japan; Malaysia; the People's Republic of China; the Philippines; the Republic of Korea; Thailand; and Taipei,China. Generally, these economies have high foreign value added embedded in their main sectors' gross exports, except for Japan, which may be involved in the very high value added segment of the transport and electrical and optical equipment sectors. The relative contributions of the main exporting sectors in these economies are also comparatively higher in gross exports than VAX_F, except in the Kyrgyz Republic. It must be noted that the Kyrgyz Republic is an economy on the borderline between categories 2 and 3. Finally, except in the Kyrgyz Republic, the relative contribution of the business services sector is also much higher in VAX_F than gross exports, leading to a lower value of HHI VAX_F than HHI GE. 
Figure 7: Herfindahl-Hirschman Index Comparisons using Gross and Value-Added Exports, Category 3, Medium- to High-Technology Manufacturing Economies

(a) Japan

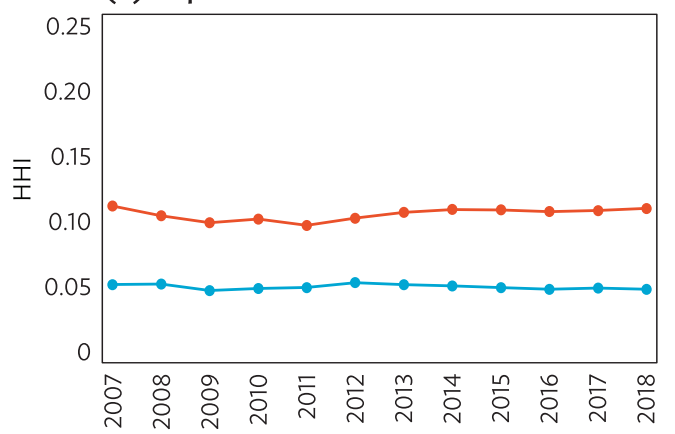

(c) Kyrgyz Republic

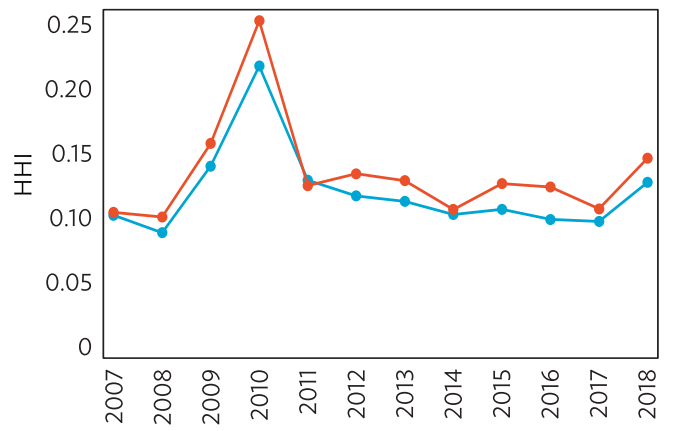

(e) People's Republic of China

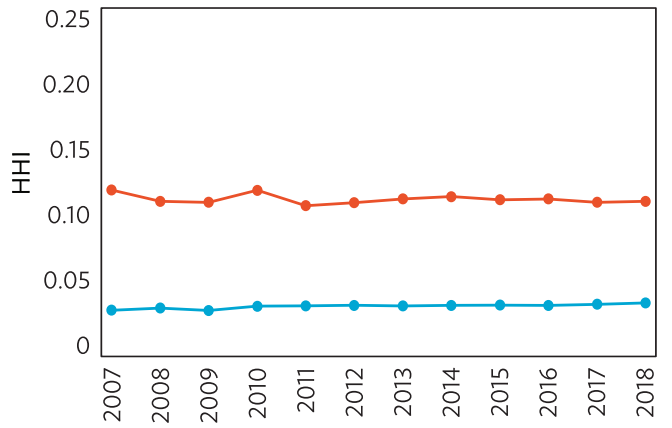

(g) Taipei,China

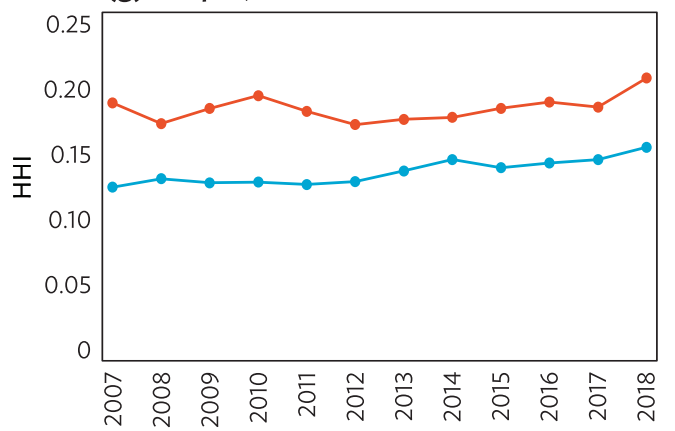

(b) Republic of Korea

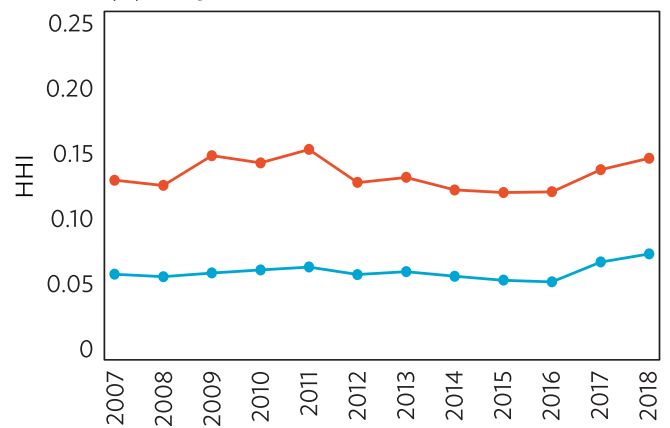

(d) Malaysia

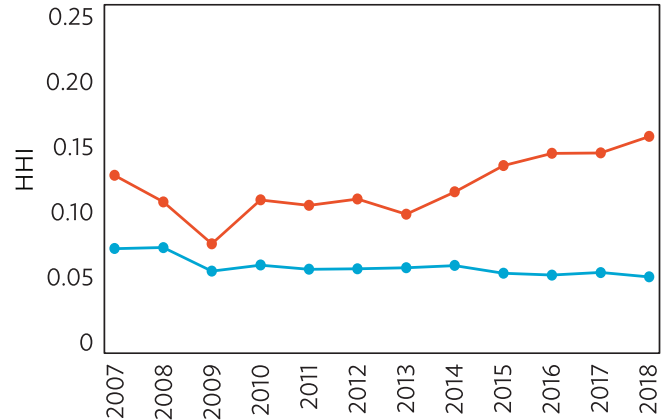

(f) Philippines

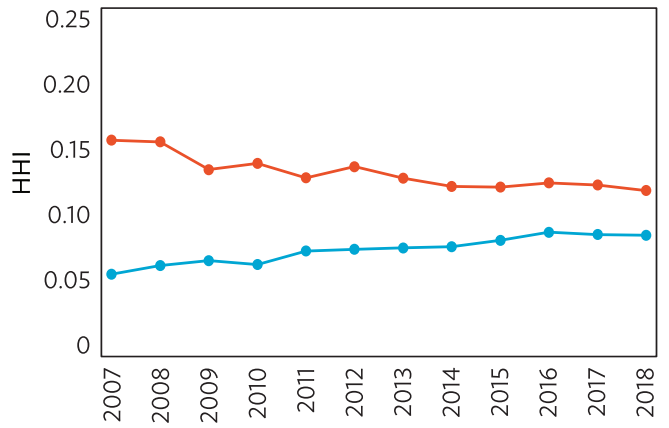

(h) Thailand

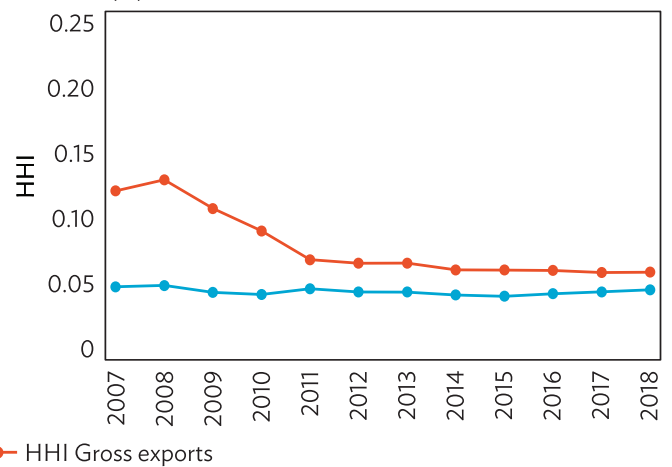

$\mathrm{GE}=$ gross exports, $\mathrm{HHI}=$ Herfindahl-Hirschman Index, VAX_F = value-added exports through the forward linkage.

Source: Authors' calculations using data from ADB Multiregional Input-Output Table. https://mrio.adbx.online/ (accessed 01 August 2021). 
The third set of economies in the third category are economies where low-technology manufacturing sectors are the top exporting sectors (Figure 8). Bangladesh, Cambodia, Pakistan and Sri Lanka have textile and textile products as their top exporting sectors, while Viet Nam's main exporting sector is food, beverages and tobacco. These economies have varying levels of foreign value added in their

Figure 8: Herfindahl-Hirschman Index Comparisons using Gross and Value-Added Exports, Category 3, Textile and Textile Products Economies

(a) Bangladesh

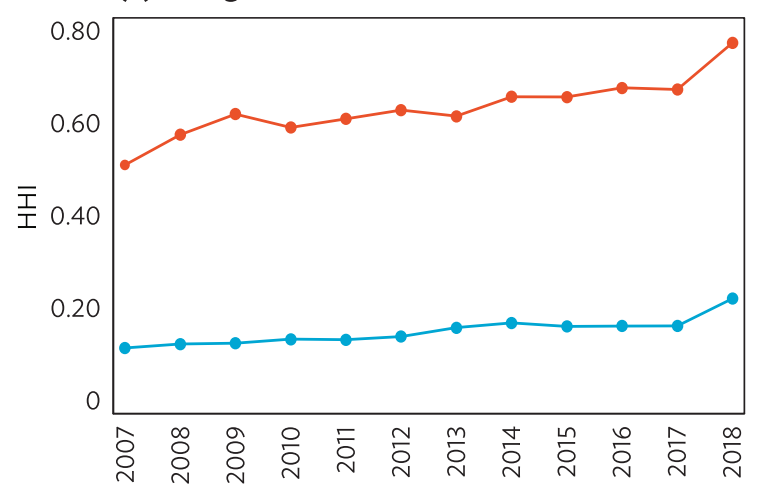

(c) Pakistan

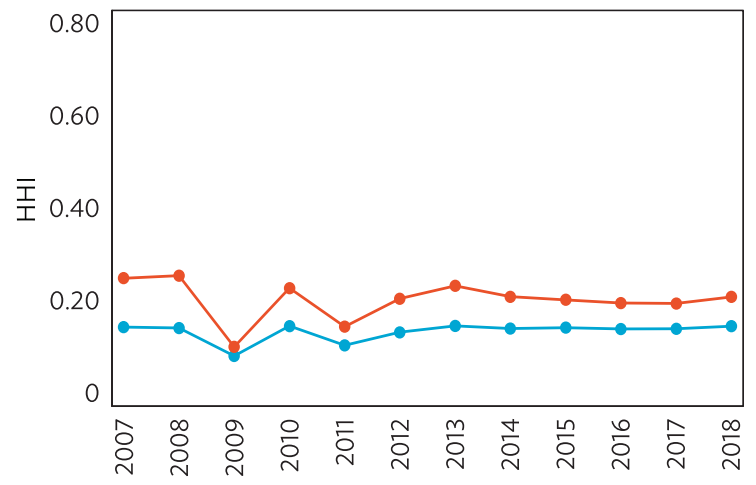

(e) Viet Nam

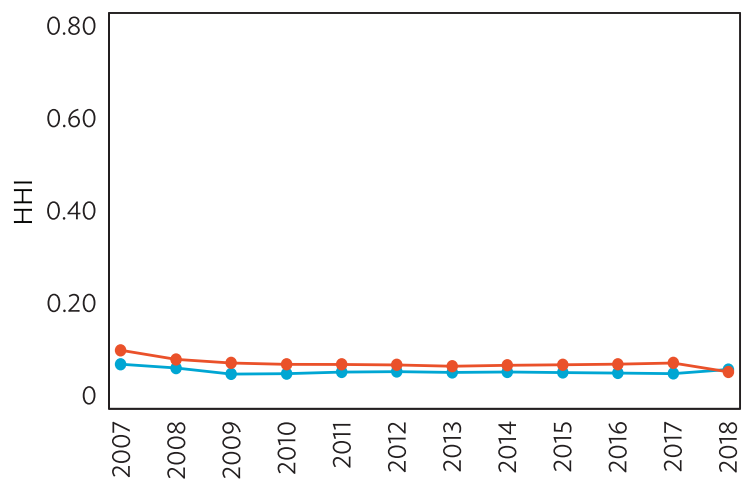

(b) Cambodia

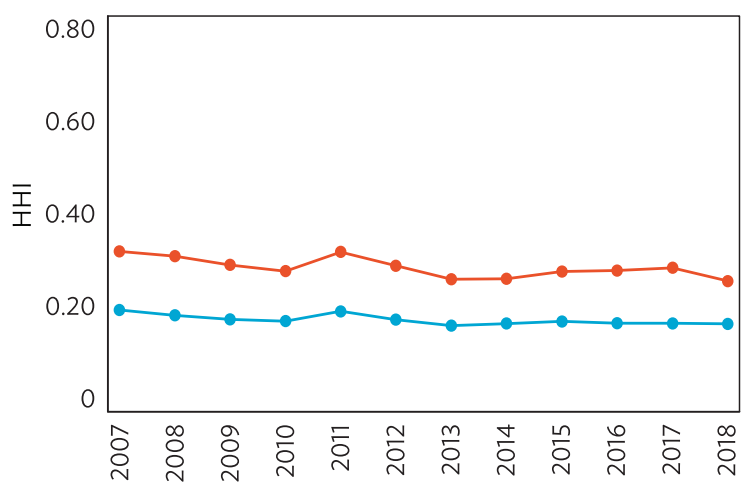

(d) Sri Lanka

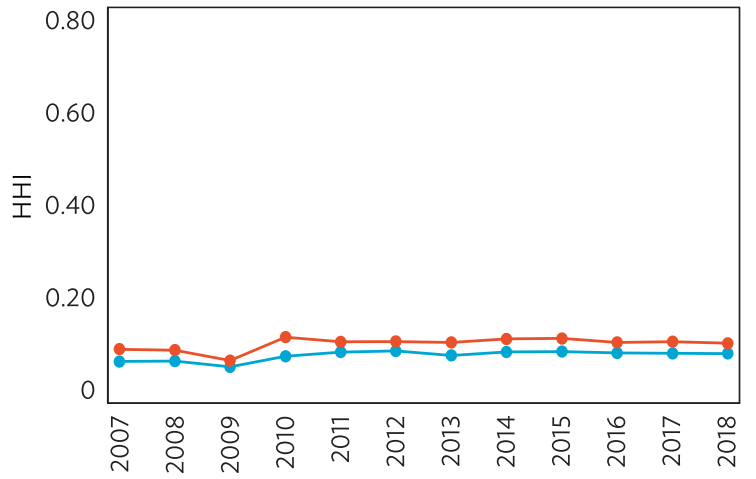

$\mathrm{GE}=$ gross exports, $\mathrm{HHI}=$ Herfindahl-Hirschman Index, VAX_F = value-added exports through the forward linkage.

Source: Authors' calculations using data from ADB Multiregional Input-Output Table. https://mrio.adbx.online/ (accessed 01 August 2021). 
main exporting sectors but Pakistan shows the lowest foreign value added embedded in its textile and textile products' gross exports at less than 10 percent. As with other economies in this category, the relative contributions of their main exporting sectors are higher in gross exports than VAX_F, but at varying degrees, going from as low as 1.4 times in Sri Lanka to as high as 3.1 times in Pakistan. One possible explanation is the position of these economies' own sector in the chain of activities for that sector. For instance, Pakistan seems to be closer to primary inputs, with its textile and textile products sector's including items that go into clothing production, while the textile and textile products sectors of Bangladesh, Cambodia, and Sri Lanka appear to be exporting ready to wear clothing items.

The last group of economies in the third category are business services-oriented economies (Figure 9). Two economies, namely Fiji and Maldives, are highly reliant on the hotel and restaurant sector for their exports. Meanwhile, Hong Kong, China has a very large wholesale trade and commission trade sector, making up over half the gross exports on average. For these three economies, their biggest sectors' relative contributions to gross exports are about 1.5 to 1.6 times more than their relative contributions to VAX_F, implying either that these business service sectors also have roles to play in the exports of other sectors or that these main business service sectors are supported by other domestic sectors.

Figure 9: Herfindahl-Hirschman Index Comparisons using Gross and Value-Added Exports, Category 3, Business Services Economies

(a) Fiji

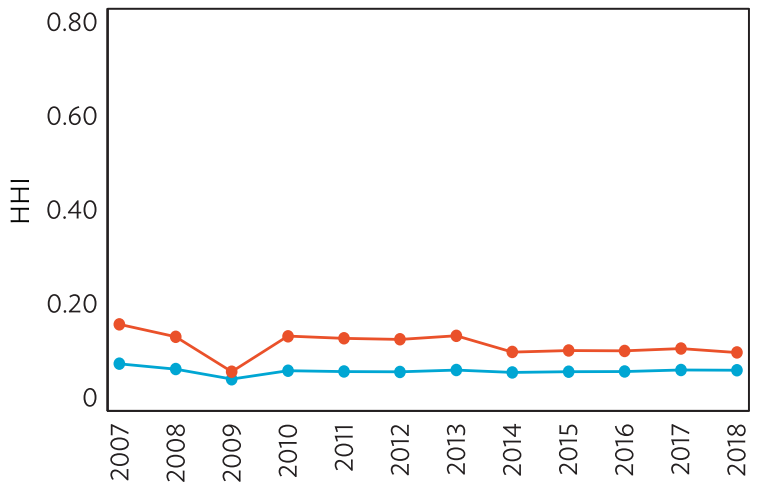

(c) Hong Kong, China

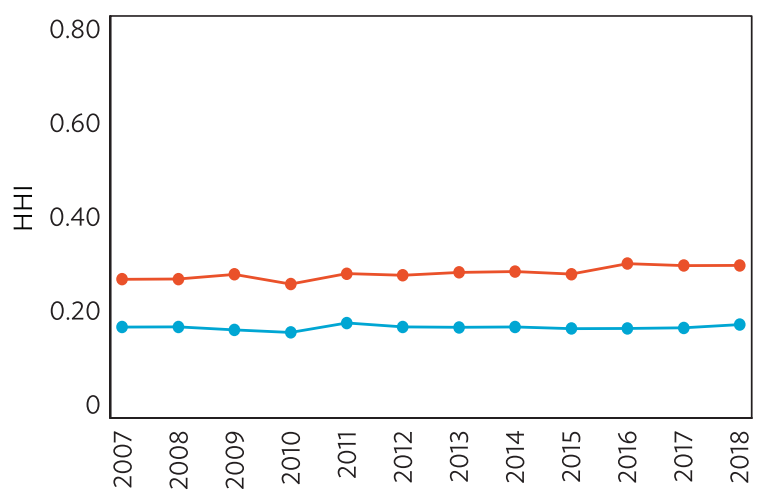

(b) Maldives

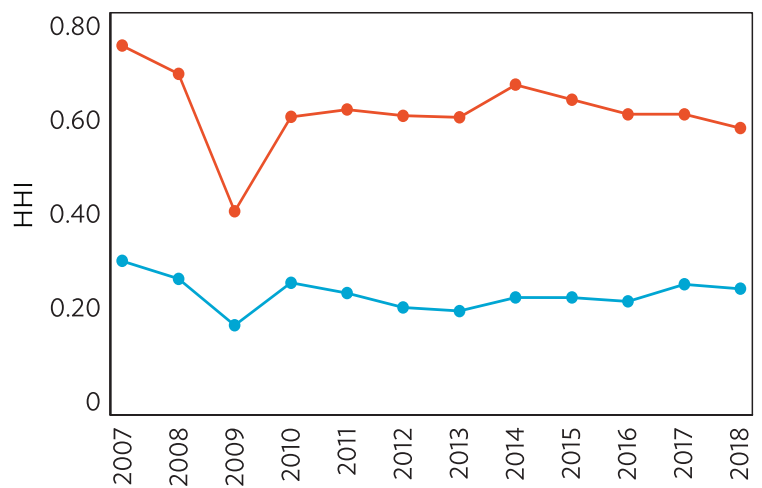

$\rightarrow$ HHI VAX_F $\rightarrow$ HHI Gross exports

$\mathrm{GE}=$ gross exports, $\mathrm{HHI}=$ Herfindahl-Hirschman Index, VAX_F = value-added exports through the forward linkage.

Source: Authors' calculations using data from ADB Multiregional Input-Output Table. https://mrio.adbx.online/ (accessed 01 August 2021). 


\section{RELATIONSHIP WITH ECONOMIC GROWTH}

Early studies, including Imbs and Wacziarg (2003), demonstrated a U-shaped relationship between economic growth (measured using income) and sectoral concentration, indicating that at low levels of income, economies increase diversification to a larger number of products, sectors and export markets. At very high levels of income, however, economies tend to focus on increased specialization, potentially driven by technological innovation in production processes, thereby tending toward more concentrated export structures.

While Imbs and Wacziarg (2003) studied a different set of economies in 1969-1997 to establish this relationship, Cadot, Carrere, and Strauss-Kahn (2011) extended the analysis to exports using more updated data (1998-2004) and inputs from the framework used by Klinger and Lederman (2004). Cadot, Carrere, and Strauss-Kahn (2011) found that up until the turning point in the U-shaped relationship, diversification trends are informed largely by the intensive margin. The paper also mapped economic growth against different indices of export diversification (e.g., Gini, Theil, and HHI indices) and estimated a similar hump-shaped relationship between economic growth (estimated using GDP per capita) and export diversification based on product-level data. This is consistent with a move away from primary exports toward more technology-intensive and manufacturing exports as one of the drivers for growth.

This section maps the relationship between HHI GE and VAX_F with economic growth (using the log of GDP per capita as an income proxy) to revisit this relationship for selected economies in Asia and the Pacific. Conventionally, as economies increase their participation in global trade, reflecting an increasing export-to-GDP ratio, they tend to aim toward greater sector-level export diversification. Further increases in export-to-GDP ratios, with increased participation in global value chains, tend to move economies toward greater sophistication and concentration in a few key sectors for exports.

While overall, economies and sectors may display trends in line with those reported by Imbs and Wacziarg (2003) and Cadot, Carrere, and Strauss-Kahn (2011), with evolving global value chains and supply chains, value-added exports based on forward linkages could provide new insights into the evolution of export diversification.

Among 26 economies in Asia and the Pacific in 2007-2018, HHI GE decreased until a certain level of income, indicating that more sectors were contributing to gross exports as economies grew from low-income levels (Figure 10). This first part of the curve is consistent with the downward part of the U-shaped curve shown by Imbs and Wacziarg (2003) and Cadot, Carrere, and Strauss-Kahn (2011). At higher income levels, the economies started to re-specialize for a limited phase in the growth process. This re-specialization is potentially driven by greater integration into value chains, an effort toward economies' relative (revealed) comparative advantages, as well as increased technological innovation. Among economies with the highest incomes, there was a trend toward diversification and stabilization in a more diversified state, indicating exports from a more diverse set of sectors. Overall, the trend was toward an increase in export diversification with income levels for gross exports. Thus, our finding that these economies display a tendency to stabilise at a more diversified export basket at higher income levels is different from the conclusions of Imbs and Wacziarg (2003) and Cadot, Carrere, and Strauss-Kahn (2011). 
Figure 10: Relationship between Gross Domestic Product and Herfindahl-Hirschman Index of Selected Economies in Asia and the Pacific, 2007-2018

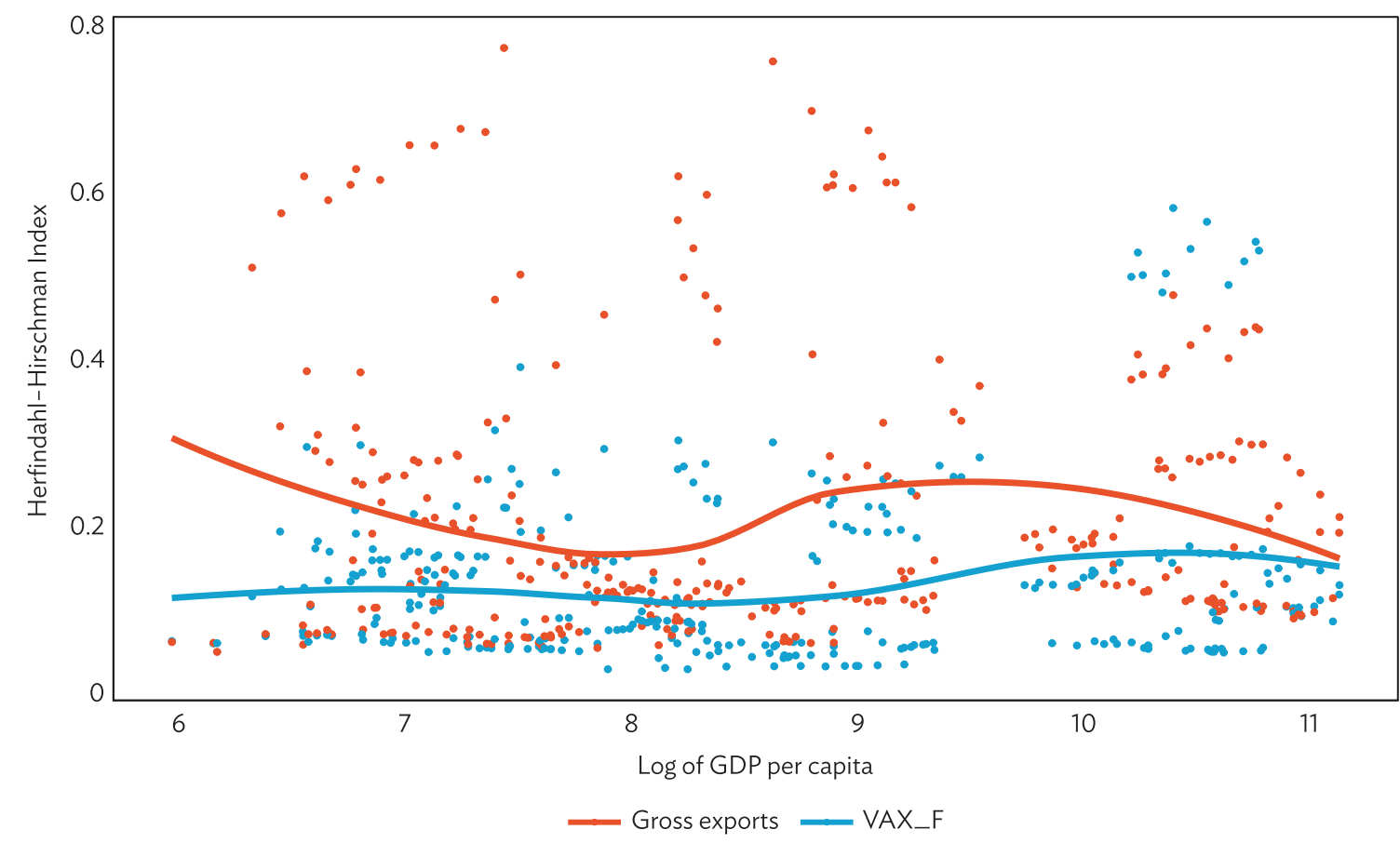

GDP = gross domestic product, VAX_F = value-added exports through the forward linkage.

Note: The orange dots are the Herfindahl-Hirschman Index $(\mathrm{HHI})$ values estimated using gross exports, while the blue dots are $\mathrm{HHI}$ values estimated using VAX_F. The orange curve is the lowess function of $\mathrm{HHI}$ gross exports data points, while the blue curve is the lowess function of HHI VAX_F data points.

Source: Authors' calculations using data from ADB Multiregional Input-Output Table. https://mrio.adbx.online/ (accessed 01 August 2021).

Across stages of growth, economies were more diversified when estimated on VAX_F than on gross exports, indicating that indirect contributions of various sectors to exports were not concentrated. HHI VAX_F slightly increased as the economies grew from low to lower middle-income levels, after which it exhibited a slight decline and then plateaued at that level up until economies started to move toward higher income levels. This would mean that as these economies grew, they tended to concentrate on value-added exports at the sector level until a certain inflexion point around the lower middle- to upper middle-income range where they started to diversify, potentially as a result of more fragmented production processes, value chain participation and technological advances. It is also noteworthy that although HHI VAX_F fluctuated as income grew, their changes were less significant than HHI GE.

For the upper middle-income category, economies re-specialized up to a certain point at very high-income levels, where economies began to re-diversify as in HHI GE. In contrast to gross exports, the general tendency was to concentrate on economic growth. At the very high-income levels, the difference between HHI GE and HHI VAX_F approaches zero. This may be the result of economies concentrating on higher value added segments as well as technological advances in the production process in both exporting sectors and the sectors that contribute to them.

Among low to lower middle-income economies, $\mathrm{HHI}$ GE started at lower levels and, at the start of the development process, they concentrated in certain sectors up until a certain level of to 
resource endowments or specialization in lower value added processes, such as assembly, as these low-income economies embed themselves in global value chains. As these economies moved toward the lower middle-income category, they started to first diversify their exports and then reconcentrate their exports, potentially as a result of technological advancements in production. Similar trends are observed for VAX_F among this group of economies.

\section{Figure 11: Relationship between Gross Domestic Product and Herfindahl-Hirschman Index of Selected Economies in Asia and the Pacific by Income Level, 2007-2018}
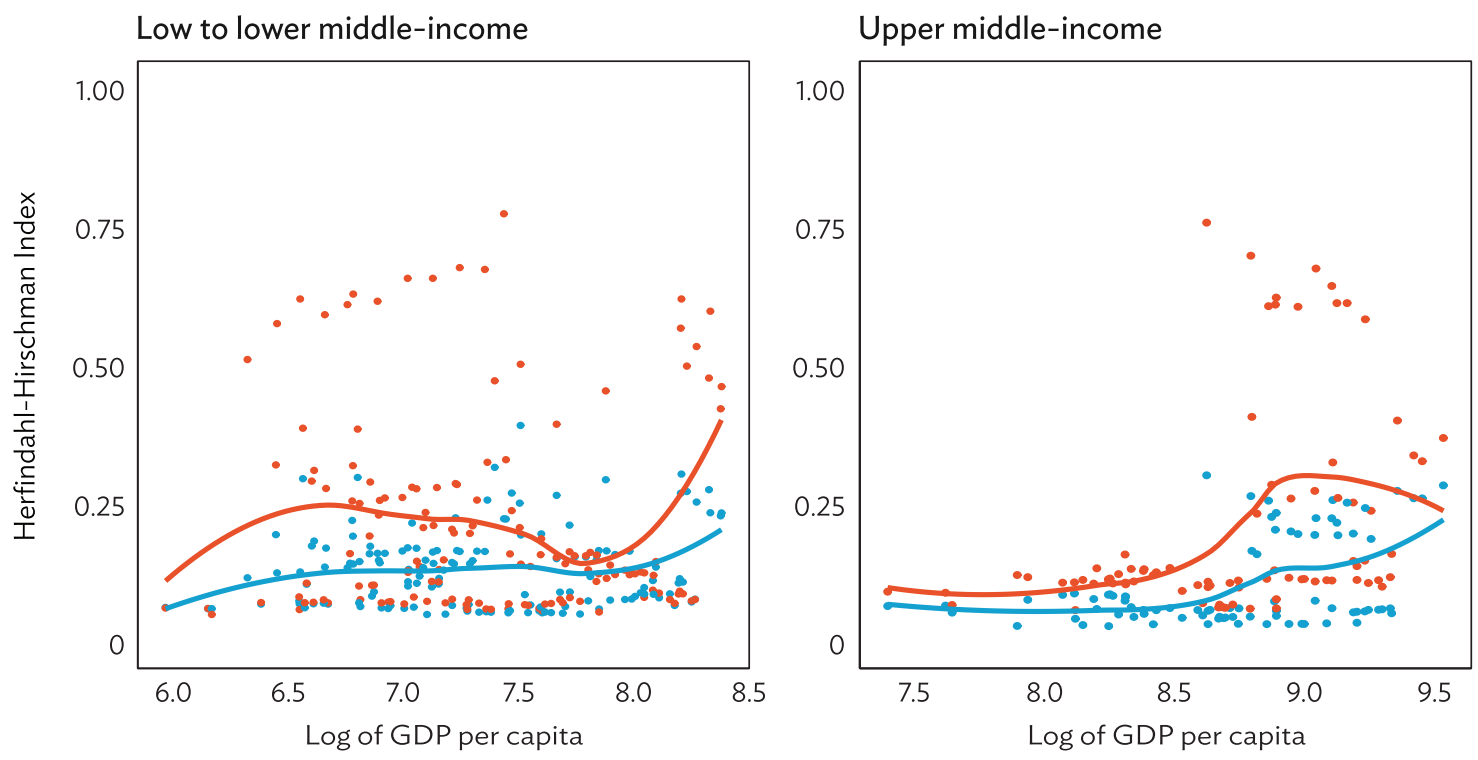

High-income

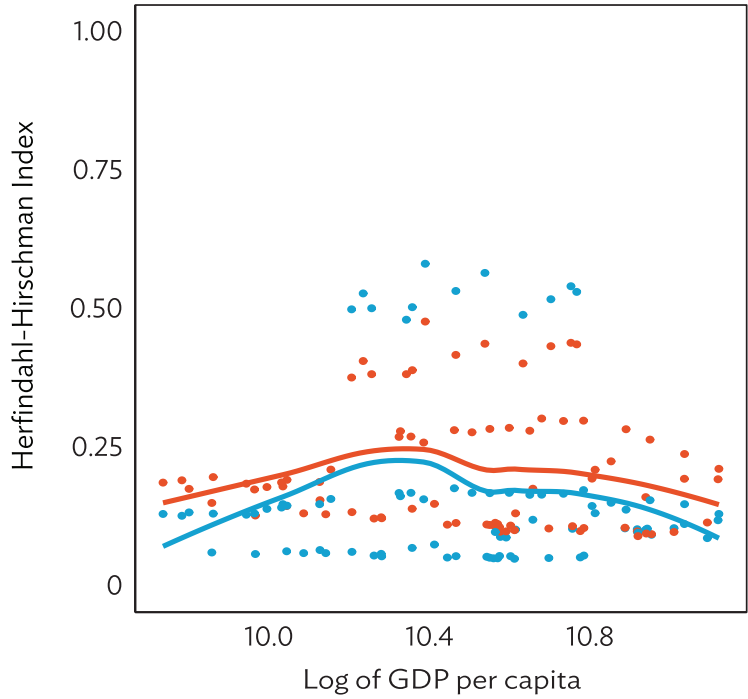

GDP = gross domestic product.

Note: The orange dots are the Herfindahl-Hirschman Index $(\mathrm{HHI})$ values estimated using gross exports, while the blue dots are $\mathrm{HHI}$ values estimated using VAX_F. The orange curve is the lowess function of $\mathrm{HHI}$ gross exports data points, while the blue curve is the lowess function of HHI VAX_F data points.

Source: Authors' calculations using data from ADB Multiregional Input-Output Table. https://mrio.adbx.online/ (accessed 01 August 2021). 
For the group of upper middle-income economies in Asia and the Pacific, the diversification trend was relatively stable in both gross exports and VAX_F. For gross exports, economies continuously concentrated at a much faster rate than in VAX_F, and then diversified thereafter, while VAX_F increased after the mid-point. At the highest income levels of this category, the economies showed similar levels of diversification in gross exports and VAX_F, higher than their counterparts at lower incomes. This points to more technological innovation, a focus on higher value-added exports, and potentially more automation of production processes. It could also indicate an increase in foreign value-added content of exports with integration into value chains.

As economies progressed from the low to lower middle-income and from the lower segments of the upper middle-income group toward the high-income category, the difference between HHI GE and $H_{H I}$ VAX_F first increases and then decreases. This might be a result of the position of economies in the production process and the corresponding level of value addition that such a step produces. For instance, many low-income economies in the sample are involved in assembly, where a large portion of inputs are imported and domestic value addition is lower. As economies learn from doing they start to expand production to other sectors and move up the value chain through higher value addition processes.

An inverse $U$-shaped relationship for both gross exports and VAX_F is observed among high-income economies, opposite to that discovered by Imbs and Wacziarg (2003) and Cadot, Carrere, and Strauss-Kahn (2011). Although the HHls closely follow the same pattern throughout, $\mathrm{HHI}$ VAX_F exhibited a faster concentration rate than HHI GE in the early part of the segment in this panel. It indicates that for these economies, dominant sectors are gaining a greater share of VAX_F than of gross exports as their income further increases until a certain income threshold. At very high-income levels, however, economies in this panel exhibited continuous diversification. As with the other panels, $\mathrm{HHI}$ VAX_F remained below $\mathrm{HHI}$ GE throughout. The $\mathrm{HHI}$ levels remained close to each other because high-income economies tend to specialize in industries where value added is already high.

There is a noticeable decline in the difference between HHI GE and HHI VAX_F as income increases (Figure 12). This is in line with the trends observed in the panels grouped by income levels in Figure 11. Despite differences in the trends in $\mathrm{HHI}$ GE and HHI VAX_F, in general, the trends for the two indices tended to converge for all income groups at higher levels of specialization. One explanation is that as economies progress, they also tend to involve themselves in higher value addition processes such as research and development or sales and marketing, leading to a lower share of foreign value added embedded in gross exports and, consequently, a smaller difference in gross exports and value added through the forward linkage. Exploring the factors driving this difference warrants further research that is beyond the scope of this paper. 


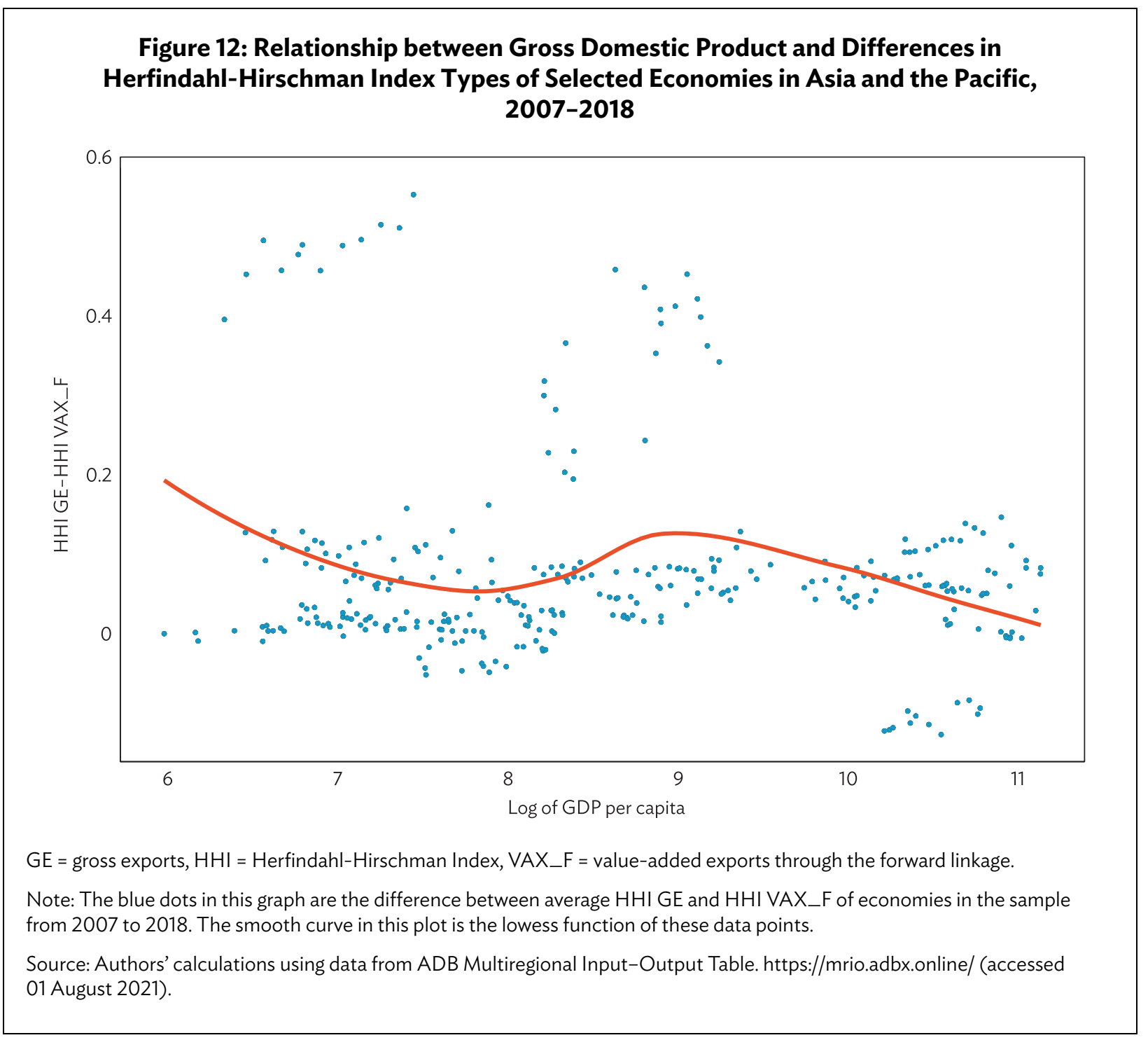

\section{CONCLUSIONS}

Global and regional interlinkages in trade with the evolution and widening of value chains have collectively resulted in more complex, fragmented production structures within trading economies. In addition, the growing role of technological finesse and higher levels of sophistication are changing the dynamics of export diversification when mapped against economic growth. This is further complicated by the increasing role of services in exports from other sectors of the economy, as well as the growing significance of digital technologies in trade. Export baskets of economies that were driven by resource endowments are now being guided by evolving relative (and revealed) comparative advantages. Assessing the relationship of export diversification, the composition and structure of these export baskets with economic growth necessarily require a comprehensive understanding of these dynamics. 
The literature discussing the benefits of export diversification as a policy objective toward economic growth is based on the mapping of the indices of export diversification (such as HHI, Gini and Theil indices) against income. Often such indices of diversification are estimated using gross exports. A more nuanced, globally integrated exporting economy requires a detailed decomposition of exports into their value-added components. Our estimates of value-added exports based on forward linkages (VAX_F) is intended to provide insight into the production complexities within exporting economies. A comparison of the $\mathrm{HHI}$ estimates using gross exports and VAX_F for the 26 economies in Asia and the Pacific from 2007 to 2018 reveals the sectors which contribute most significantly to exports, trends in export diversification and the relationship between export diversification and income. The paper revisited the relationship established by Imbs and Wacziarg (2003) and Cadot, Carrere, and Strauss-Kahn (2011) and shows a much more complex relationship than a simple $\mathrm{U}$-shaped curve. Trends are dependent on the diversification indicator and vary by income category. One general finding is that divergence between the diversification in export sectors and sectors contributing to exports narrowed as income levels of economies increase.

The trends revealed in this paper indicate that in the estimation and assessment of export diversification, while gross exports provide an insight into the direct exports of a trading economy they do not address the full story. Estimating export diversification using VAX_F (HHI VAX_F) and reading that in parallel with the estimate using gross exports ( $\mathrm{HHI} G \mathrm{G})$ provides a more detailed and comprehensive picture of the export structure of the economy, including the sectors that contribute to exports indirectly. The two indices answer different but complementary policy questions. For example, $\mathrm{HHI}$ GE can give an indication of the vulnerability of economies when faced with exogenous shocks, while HHI VAX_F might indicate how these shocks will be propagated within economies. Furthermore, HHI VAX_F can also give an indication of how inclusive growth might be. Such a comprehensive assessment can better inform policy decisions and enable exporting economies to carve their niche in the rapidly growing and increasingly digitally-enabled value chains. 


\section{REFERENCES}

Acemoglu, Daron, and Fabrizio Zilibotti. 1997. "Was Prometheus Unbound by Chance? Risk Diversification and Growth." Journal of Political Economy 105: 709-51.

Adajar, Paolo M., Ernst R. Berndt, and Rena M. Conti. 2019. "The Surprising Hybrid Pedigree of Measures of Diversity and Economic Concentration." NBER Working Paper No. 26512. National Bureau of Economic Research, Cambridge, MA.

Agosin, Manuel R. 2007. "Export Diversification and Growth in Emerging Economies." Working Paper No. 233. Universidad de Chile Departamento de Economía, Santiago, Chile.

Cadot, Olivier, Celine Carrere, and Vanessa Strauss-Kahn. 2011. "Export Diversification: What's Behind the Hump?" The Review of Economics and Statistics 93 (2): 590-605.

de Piñeres, Sheila Amin, and Michael J. Ferrantino, 2000. Export Dynamics and Economic Growth in Latin America: A Comparative Perspective. London: Routledge.

Hausmann, Roridk, Jason Hwang, and Dani Rodrik. 2006. "What You Export Matters." CID Working Paper No. 123. Centre for International Development, Harvard University, Cambridge, MA.

Hausmann, Ricardo, and Dani Rodrik. 2003. "Economic Development as Self-Discovery.” Journal of Development Economics 72 (2): 603-33.

Hausmann, Ricardo, and Bailey Klinger. 2006. "Structural Transformation and Patterns of Comparative Advantage in the Product Space." CID Working Paper No. 128. Centre for International Development, Harvard University, Cambridge, MA.

Hesse, Heiko. 2008. "Export Diversification and Economic Growth." Commission on Growth and Development Working Paper No. 21. World Bank, Washington, DC.

Hummels, David, Jun Ishii, and Kei-Mu Yi. 2001. "The Nature and Growth of Vertical Specialization in World Trade." Journal of International Economics 54 (1): 75-96.

Imbs, Jean, and Romain Wacziarg. 2003. "Stages of Diversification." American Economic Review 93 (1): 63-86.

Klinger, Bailey, and Daniel Lederman. 2004. Discovery and Development: An Empirical Exploration of New Products. https://ssrn.com/abstract $=625328$.

Krugman, Paul. 1980. "Scale of Economies, Product Differentiation and the Pattern of Trade." American Economic Review (70) 5: 950-59.

Palan, Nicole. 2010. "Measurement of Specialization: The Choice of Indices." FIW Working Paper No. 62. Research Centre International Economics, Vienna.

Romer, Paul M. 1990. “Endogenous Technological Change.” Journal of Political Economy. 98 (5): 71-102. 
UNCTAD. n.d. "Measurement of Services Value-Added in Exports and Analysis of Related Services and Trade Policies." Webpage. United Nations Conference on Trade and Development, Geneva. https://unctad.org/project/measurement-services-value-added-exports-and-analysis-relatedservices-and-trade-policies.

Wang, Zhi, Shang-Jin Wei, and Kunfu Zhu. 2013. "Quantifying International Production Sharing at the Bilateral and Sector Levels." NBER Working Paper Series No. 19677. National Bureau of Economic Research, Cambridge, MA. 


\section{A Case for Value-Added Exports in the Estimation of Export Diversification in Asia and the Pacific}

As economies integrate into global and regional value chains, these fragmented production structures may not be adequately reflected in diversification measurements based on gross exports. This paper develops a new indicator of export diversification based on value added in export contributing sectors. The trends indicate that while an assessment of export diversification using gross exports provides an insight into the direct exports of a trading economy, it does not tell the full story. Using both gross exports and value-added exports can better inform policy decisions and enable exporting economies to carve their niche in increasingly digitally-enabled value chains.

\section{About the Asian Development Bank}

ADB is committed to achieving a prosperous, inclusive, resilient, and sustainable Asia and the Pacific, while sustaining its efforts to eradicate extreme poverty. Established in 1966, it is owned by 68 members -49 from the region. Its main instruments for helping its developing member countries are policy dialogue, loans, equity investments, guarantees, grants, and technical assistance. 